\title{
Upper mantle structure around the Trans-European Suture Zone obtained by teleseismic tomography
}

\author{
I. Janutyte ${ }^{1,5,6}$, M. Majdanski ${ }^{2}$, P. H. Voss ${ }^{3}$, E. Kozlovskaya ${ }^{4}$, and PASSEQ Working Group ${ }^{7}$ \\ ${ }^{1}$ NORSAR, Kjeller, Norway \\ ${ }^{2}$ Institute of Geophysics Polish Academy of Sciences, Warsaw, Poland \\ ${ }^{3}$ Geological Survey of Denmark and Greenland - GEUS, Copenhagen, Denmark \\ ${ }^{4}$ Sodankylä Geophysical Observatory/Oulu Unit, University of Oulu, Oulu, Finland \\ ${ }^{5}$ Vilnius University, Vilnius, Lithuania \\ ${ }^{6}$ Lithuanian Geological Survey, Vilnius, Lithuania \\ ${ }^{7}$ indicated in Acknowledgements \\ Correspondence to: I. Janutyte (ilma@norsar.no)
}

Received: 1 July 2014 - Published in Solid Earth Discuss.: 18 July 2014

Revised: 9 December 2014 - Accepted: 15 December 2014 - Published: 16 January 2015

\begin{abstract}
The presented study aims to resolve the upper mantle structure around the Trans-European Suture Zone (TESZ), which is the major tectonic boundary in Europe. The data of 183 temporary and permanent seismic stations operated during the period of the PASsive Seismic Experiment (PASSEQ) 2006-2008 within the study area from Germany to Lithuania was used to compile the data set of manually picked 6008 top-quality arrivals of $\mathrm{P}$ waves from teleseismic earthquakes. We used the TELINV nonlinear teleseismic tomography algorithm to perform the inversions. As a result, we obtain a model of $\mathrm{P}$ wave velocity variations up to about $\pm 3 \%$ with respect to the IASP91 velocity model in the upper mantle around the TESZ. The higher velocities to the east of the TESZ correspond to the older East European Craton (EEC), while the lower velocities to the west of the TESZ correspond to younger western Europe. We find that the seismic lithosphere-asthenosphere boundary (LAB) is more distinct beneath the Phanerozoic part of Europe than beneath the Precambrian part. To the west of the TESZ beneath the eastern part of the Bohemian Massif, the Sudetes Mountains and the Eger Rift, the negative anomalies are observed from a depth of at least $70 \mathrm{~km}$, while under the Variscides the average depth of the seismic LAB is about $100 \mathrm{~km}$. We do not observe the seismic LAB beneath the EEC, but beneath Lithuania we find the thickest lithosphere of about $300 \mathrm{~km}$ or more. Beneath the TESZ, the asthenosphere is at a depth of 150$180 \mathrm{~km}$, which is an intermediate value between that of the
\end{abstract}

EEC and western Europe. The results imply that the seismic LAB in the northern part of the TESZ is in the shape of a ramp dipping to the northeasterly direction. In the southern part of the TESZ, the LAB is shallower, most probably due to younger tectonic settings. In the northern part of the TESZ we do not recognize any clear contact between Phanerozoic and Proterozoic Europe, but further to the south we may refer to a sharp and steep contact on the eastern edge of the TESZ. Moreover, beneath Lithuania at depths of $120-150 \mathrm{~km}$, we observe the lower velocity area following the boundary of the proposed paleosubduction zone.

\section{Introduction}

\subsection{Tectonic settings}

The Trans-European Suture Zone (TESZ) is the most fundamental lithospheric boundary in Europe (Pharao, 1999) that marks the transition between the old Proterozoic lithosphere of the East European Craton (EEC) and the younger Phanerozoic lithosphere of central and western Europe (Fig. 1a). The EEC, the Baltica segment to the east of the TESZ, comprises three paleocontinents: Sarmatia, Volgo-Uralia and Fennoscandia (Bogdanova et al., 2006), with significant sutures in between them. The territories in the northeastern part of the EEC consist of several Svecofennian crustal 
units (Fig. 1b), such as the Belarus-Podlasie Granulite Domain (BPG), the East Lithuanian Domain (EL) and the West Lithuanian Granulite Domain (WLG), which continue in a NE-SW direction into Poland and terminate at the TESZ (Bogdanova et al., 2006). The area in between the EL and the WLG is called the Middle Lithuanian Suture Zone (MLSZ), which was interpreted as a paleosubduction zone along which the EL subducted under the WLG about $1.83 \mathrm{Ga}$ (Motuza, 2004, 2005; Motuza and Staškus, 2009).

To the west of the TESZ, the structure of the lithosphere is much more complex compared to the lithosphere of the EEC (e.g., Zielhuis and Nolet, 1994; Dadlez et al., 2005; Knapmeyer-Endrun et al., 2013a; Babuška and Plomerova, 2001) (Fig. 1a). The territories in central-western Europe consist of various continental fragments that were subsequently rifted off the northern margin of Gondwana and accreted to the southwestern margin of the Precambrian Baltica during a number of orogenic events (Nolet and Zielhuis, 1994; Pharaoh, 1999; Winchester and the PACE TMR Network Team, 2002; Banka et al., 2002). The TESZ contains two pronounced linear segments: the SorgenfreiTornquist Zone (STZ) in the northwestern part of the TESZ between Sweden and Denmark-Germany, and the TeisseyreTornquist Zone (TTZ) stretching from the Baltic Sea in the northwest to the Black Sea in the southeast. The territories around the TESZ formed during four major geological stages: (1) Caledonian collision tectonics, (2) Variscian orogeny, (3) Mesozoic rifting, and (4) Alpine orogenic events (Bogdanova et al., 2007; Thybo, 2000). During the Cambrian period, the terrains of Lysogory, Malopolska and BrunoSilesian accreted to Baltica, forming southern Poland and the eastern edge of the Bohemian Massif (Belka et al., 2000). During the Caledonian orogeny, the Avalonian segment closing the Tornquist Ocean accreted to the eastern margin of Baltica (Pharaoh, 1999). The Variscan orogeny from the late Silurian to early Carboniferous resulted in a junction of three paleomicrocontinents: Saxothuringian, Moldanubian and Tepla-Barrandian, in the territory of Vogtland and northwestern Bohemia (Franke and Zelazniewicz, 2000). The Saxothuringian is juxtaposed with the Moldanubian in a broad contact indicating a paleosubduction of the Saxothuringian, possibly with a piece of the oceanic lithosphere beneath the Moldanubian (Plomerova et al., 1998). The "triple junction" resulted in the crust and lithosphere thinning as well as the tectono-sedimentary evolution of the Cheb Basin situated above the junction. The basin formed between the late Oligocene and Pliocene by reactivation of the Variscan junction of the three lithospheric blocks (Babuška et al., 2007). During the Cretaceous to Cenozoic periods, a number of terrains accreted to western Europe, resulting in the Alpine and Carpathian orogenies. During the middle to late Eocene, rifting processes took place in central Europe, followed by the quaternary volcanism (Wagner et al., 2002; Babuška et al., 2007) that was possibly related to the upper mantle reservoir (Babuška and Plomerova, 2001; Zhu et al.,

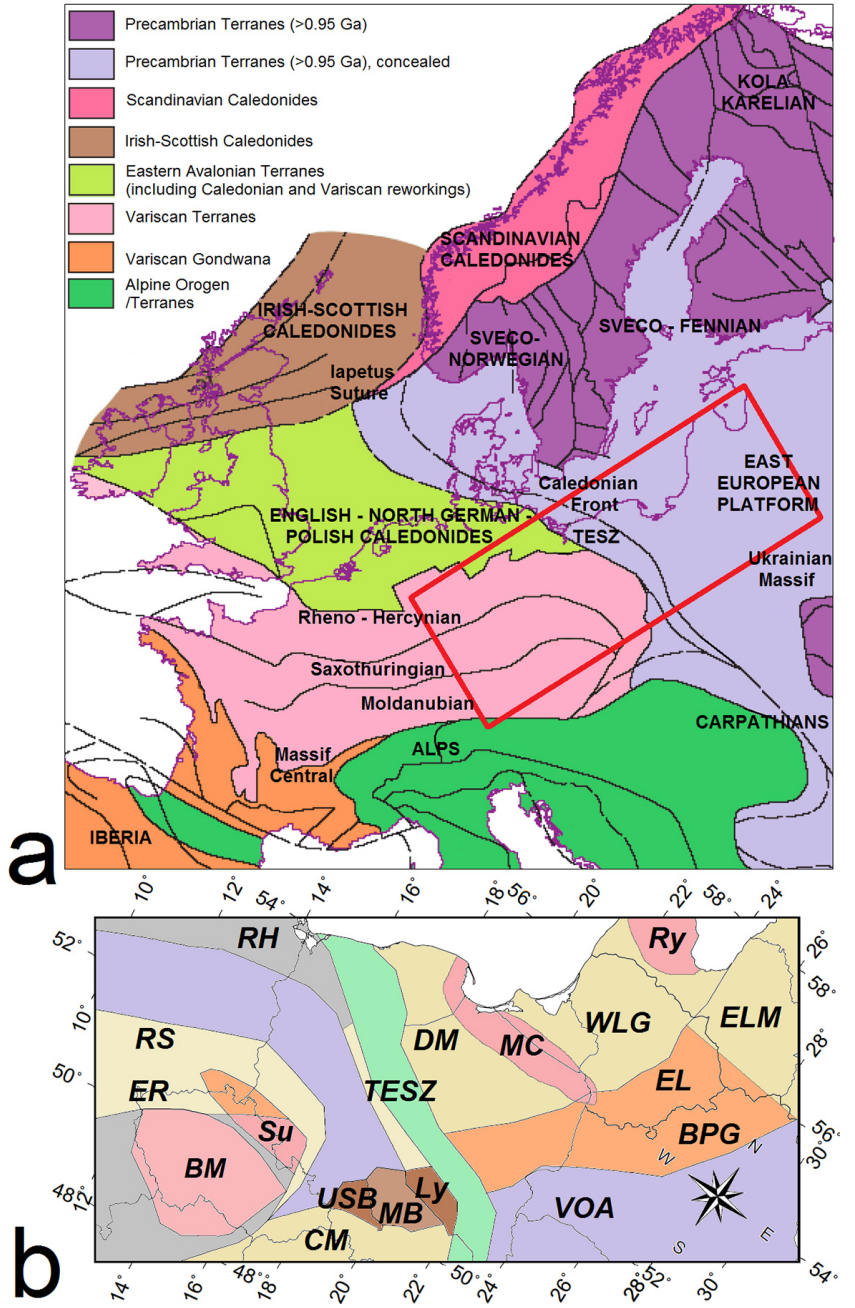

Figure 1. (a) Simplified tectonic sketch of Precambrian and Phanerozoic Europe (after Blundell et al., 1992). Study area indicated by red rectangle. (b) Tectonic sketch of the study area compiled from Skridlaite and Motuza (2001), Malinowski et al. (2008), Guterch et al. (1999), Bogdanova et al. (2001), and Gee and Stephenson (2006). Units: BM, Bohemian Massif; BPG, BelarusPodlasie Granulite Belt; CM, Carpathian Mountains; DM, Dobrzyn Massif; EL, East Lithuanian Domain; ELM, East Latvian Massif; ER, Eger Rift; Ly, Lysogory; MB, Malopolska Block; MC, Mazury Complex; RH, Rheno-Herzynian Front; RS, Rheic Suture; Ry, Riga batholith; Su, Sudetes Mountains; TESZ, Trans-European Suture Zone; USB, Upper Silesian Coal Basin; VOA, Volyn-Orsha aulacogen; WLG, West Lithuanian Granulite Domain.

2012). The developed Tertiary Eger Rift continues $300 \mathrm{~km}$ in the ENE-WSW direction and follows the late Variscan mantle transition between the Saxothuringian and the TeplaBarrandian. 


\subsection{Review of previous studies}

Due to a long evolution and complex tectonic structure, the TESZ and the surrounding territories have always been a subject of great interest in geosciences. The structure of the crust and uppermost mantle around the TESZ has been studied intensively during the controlled-source seismic experiments - long-range deep seismic sounding (DSS) profiles (e.g., Guterch et al., 1999, 2004; Grad et al., 2002, 2006; EUROBRIDGE Seismic Working Group, 1999; Pharaoh and TESZ Project Core Group, 2000). The obtained results show large variations of average thickness of the continental crust: the Moho depth varies from $28-35 \mathrm{~km}$ beneath the Paleozoic platform (Guterch and Grad, 1996; Pharaoh et al., 1997; Guterch et al., 1999) to $40-50 \mathrm{~km}$ beneath the western part of the EEC adjoining the TESZ and even deeper farther to the northeast (Grad et al., 2006; Guterch et al., 2004). The projects provided sufficient information about the crustal structure around the area, which was used to compile some precise 3-D crustal models (e.g., Majdanski, 2012). Using data of the DSS projects, the EUROBRIDGE Working Group (1999), Czuba et al. (2001), Yliniemi et al. (2004), Grad et al. (2002) and Thybo et al. (2003) found some reflectors in the upper mantle just beneath the Moho going down to $75 \mathrm{~km}$ in Fennoscandia, which could be related to different crustal units. Similar subhorizontal lithospheric reflectors were observed beneath the TESZ (Grad et al., 2002; Guterch et al., 2004) and the Baltic Sea (Hansen and Balling, 2004). However, the depths of resolution of the DSS profiles are usually limited to about $50-80 \mathrm{~km}$.

Compared to the crust, the structure of the lithosphere and the lithosphere-asthenosphere boundary (LAB) in the TESZ and its surroundings is poorly known. While it was found that the cratonic lithosphere extends much deeper than that of the younger continental regions (e.g., Plomerova et al., 2002; Eaton et al., 2009; Shomali et al., 2006; Gregersen et al., 2010), the studies revealed that the structure of the lithosphere and the LAB differs a lot on both sides of the TESZ (e.g., Zielhuis and Nolet, 1994; Majorowicz et al., 2003; Artemieva et al., 2006; Koulakov et al., 2009; WildePiórko et al., 2010). Regarding different physical properties and geophysical techniques, the LAB has different practical definitions: (1) the seismic LAB defines the transition between the solid outer layer of the Earth, which is characterized by higher seismic velocity values, and its interior, which is characterized by lower seismic velocity values; (2) the thermal LAB defines the transition between the outer layer with dominating conductive heat transfer above the convective mantle that usually coincides with a depth of a constant isotherm of about $1300{ }^{\circ} \mathrm{C}$ (McKenzie, 1967); (3) the electrical LAB is a transition between the generally electrically resistive outer layer of the Earth and the conductive layer in the upper mantle.

The studies by Majorowicz et al. (2003) and Artemieva et al. (2006) based on global tomography and heat flow mea- surements indicate that beneath the EEC the thickness of the thermal lithosphere is about $180-200 \mathrm{~km}$, while the thickness of the seismic lithosphere is more than $250 \mathrm{~km}$. The results by Artemieva et al. (2006) were obtained using all available data resulting from the wide-angle studies by Vinnik and Ryaboy (1981), Garetskii et al. (1990), Grad and Tripolsky (1995), Kostyuchenko et al. (1999), the EUROBRIDGE Working Group and EUROBRIDGE'95 (2001), Grad et al. (2002), and Thybo et al. (2003), and the results of P and S wave tomography by Matzel and Grand (2004). These data are sparse compared to the study area, and the spatial resolution is questionable; however, the thick seismic lithosphere reported by Artemieva et al. (2006) was also found in the area during other studies. Koulakov et al. (2009) observed the positive $\mathrm{P}$ wave velocity anomaly beneath the EEC down to at least $300 \mathrm{~km}$, which indicates even thicker lithosphere compared to Artemieva et al. (2006). Legendre et al. (2012) find no indications of a deep cratonic root below about $330 \mathrm{~km}$ for the EEC, while Geissler et al. (2010) do not observe any clear indications of deep seismic LAB beneath the EEC either.

In central-western and northern Europe, the TOR 19961997 passive seismic project, which was carried out across the STZ, provided a detailed model of the upper mantle and the LAB (Gregersen et al., 1999; Plomerova and Babuska, 2002; Shomali et al., 2006; Artlitt, 1999; Cotte et al., 2002). The results show that the average thickness of the seismic lithosphere is about $100 \mathrm{~km}$ in central Europe, which coincides with global tomography studies by Artemieva et al. (2006) and the studies of S receiver functions by Geissler et al. (2010). The results obtained from the TOR data indicate that beneath the TESZ the thickness of the seismic lithosphere is about $120 \mathrm{~km}$, which is an intermediate value between that of the EEC and western Europe (Shomali et al., 2006; Wilde-Piórko et al., 2010), while the transition beneath the STZ is near-vertical, with only a weak tendency to the northeastern slope (Gregersen et al., 2010). Geissler et al. (2010) indicate the lithosphere thickness of about 115$130 \mathrm{~km}$ in the vicinity of the TESZ, while the LAB beneath the southwestern part of the Variscan Bohemian Massif is estimated at a depth of $115 \mathrm{~km}$, and the thin lithosphere of only about $75 \mathrm{~km}$ is reported beneath some parts of the Pannonian Basin. Beneath the Bohemian Massif, an extensive low-velocity heterogeneity in the upper mantle is found (Koulakov et al., 2009; Karousova et al., 2013), while the high-resolution tomography studies indicate the most distinct low-velocity perturbations along the Eger Rift down to about $200 \mathrm{~km}$ (Karousova et al., 2013). Plomerova et al. (2007) interpret the broad low-velocity anomaly beneath the Eger Rift as an upwelling of the LAB. The authors also find different orientations of seismic anisotropy corresponding to the major tectonic units in the Bohemian Massif (i.e., Saxothuringian, Moldanubian and Tepla-Barrandian), while the studies of shear-wave splitting (e.g., Wüstefeld et al., 2010; Vecsey et al., 2013; Sroda et al., 2014) show that anisotropy in the 
Bohemian Massif is higher compared to the anisotropy observed in the TESZ and even smaller, but still noticeable, for the EEC (Plomerova et al., 2008).

Jones et al. (2010) performed a comparison between the delineation of the LAB for Europe based on seismological and electromagnetic observations, and concluded that the $\mathrm{LAB}$, as an impedance contrast from receiver functions, as a seismic anisotropy change and as an increase in conductivity from magnetotellurics, are consistent with the deeper $\mathrm{LAB}$ beneath the EEC and the shallower LAB beneath central Europe, which coincides with conclusions by Korja (2007), who made a review of previous studies of magnetotelluric imaging of the European lithosphere. Jones et al. (2010) found that the seismic and electric LABs beneath Phanerozoic Europe are at depths of about $90-100 \mathrm{~km}$, while for the EEC, they differ, and the electric LAB is at a depth of about $250 \mathrm{~km}$. The studies also show anomalously thick electrical LAB beneath the TESZ, whereas the seismic LAB should be much shallower. The authors imply that the difference could be caused by increased partial melting or by hydration beneath the TESZ.

An opportunity to enhance knowledge of the lithosphere structure and the LAB around the TESZ was implemented during the international PASsive Seismic Experiment (PASSEQ) 2006-2008 (Wilde-Piorko et al., 2008), which aimed to study the lithosphere and asthenosphere around the TESZ. The aim of this study is to obtain a model of the upper mantle and the seismic LAB on a regional scale in the territory around the TESZ (Fig. 1b) using data from the seismic stations operated in the region during the PASSEQ project and the method of teleseismic tomography.

\section{Data set}

The PASsive Seismic Experiment (PASSEQ) 2006-2008 (Wilde-Piorko et al., 2008) was carried out from June 2006 to July 2008 in the territory extending from Germany and the Czech Republic throughout Poland to Lithuania where 139 short-period and 49 broadband temporary seismic stations were deployed (Fig. 2). In this study, we use data of the PASSEQ project and some permanent seismic stations operated in the area during the period of the PASSEQ project. Although there were over 200 temporary seismic stations deployed in the region, due to some technical peculiarities, in total we used data of 183 seismic stations. From the seismological bulletins of the International Seismological Centre (ISC), we selected 101 teleseismic earthquakes (EQs) with a magnitude range of 5.5 to 7.2 and an epicentral distance of 30 to 92 degrees with respect to the point at the LithuanianPolish border at $23^{\circ} \mathrm{E}$ and $54^{\circ} \mathrm{N}$ (Table A1). The majority of the selected EQs are located to the east of the target area (i.e., Sumatra, Japan, Kamchatka and the Aleutian regions) due to naturally higher seismicity compared to the regions to the west of the study area; thus, the largest seismic gap of about

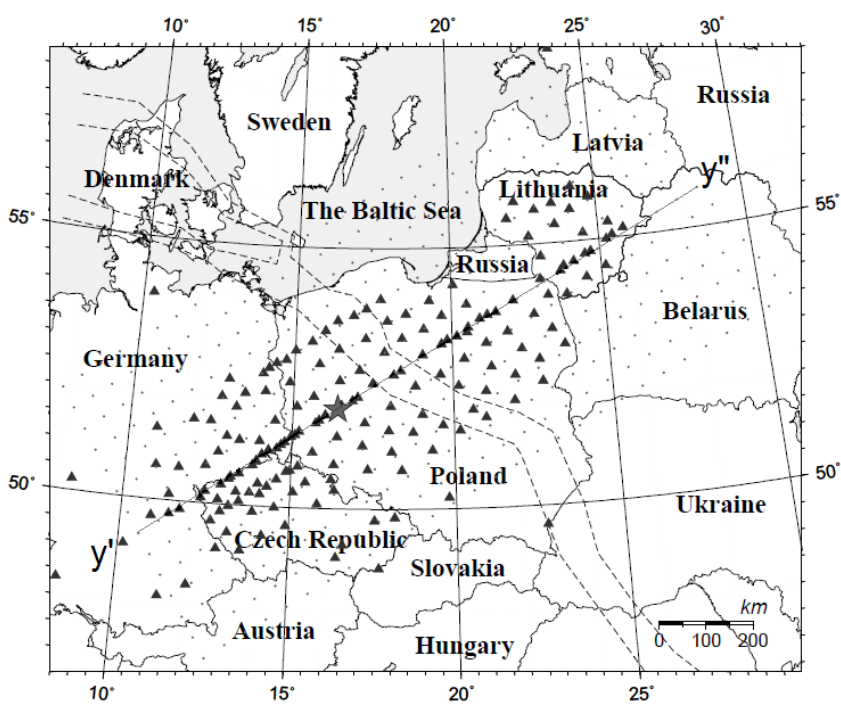

Figure 2. Seismic stations used in this study marked as triangles. Dots indicate nodes of the model grid. Star indicates origin of the local Cartesian coordinate system used. Dashed lines indicate the TESZ. Solid line $y^{\prime} y^{\prime \prime}$ marks the main PASSEQ transect at $y=0$ in the local Cartesian coordinate system.

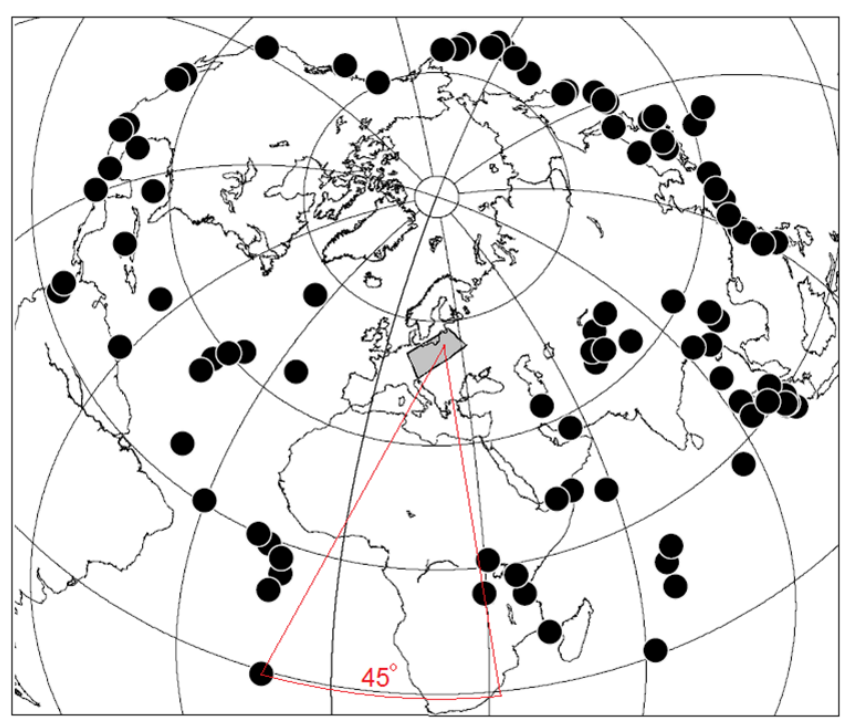

Figure 3. Map of epicenters of EQs (black circles) used in our study. Grey rectangle indicates the study area. Red lines show the largest seismic gap.

45 degrees is for the region of Africa and the southern part of the Atlantic Ocean (Fig. 3). Using the Seismic Handler Motif (SHM) (http://www.seismic-handler.org/) program package, we analyzed the data and compiled the data set of 6008 manually picked top-quality absolute $\mathrm{P}$ wave arrivals. The weighting factor of the picks was assigned according to the picking error, which was set to less than $0.2 \mathrm{~s}$ for the topquality data. The picking error of the top-quality picks was 
usually much smaller $(<0.1 \mathrm{~s})$ because of good data quality; however, the large interval of the error was selected before the data analysis in order to ensure a reasonable number of the top-quality picks.

The calculation of theoretical travel times (TT) of the $\mathrm{P}$ wave arrivals was performed using the EQ location information from the ISC seismological bulletins and the Seismic Handler (SH) program, which applies the IASP91 velocity model. The TT residuals were calculated as follows:

$T_{\text {picked }}-T_{\text {theoretical }}=\mathrm{TR}$,

where $T_{\text {picked }}$ is the observed TT, $T_{\text {theoretical }}$ is the theoretical TT calculated with SH, and TR is the TT residual. It was noticed that the calculated values of the TT residuals are higher to the west and lower to the east from the TESZ, which might be related to different tectonic-geological settings in the area.

\section{Teleseismic tomography inversion method}

We used the TELINV nonlinear teleseismic tomography code (Weiland et al., 1995) to perform the inversions. In teleseismic tomography, the perturbations of the TT are used to estimate the size and magnitude of the velocity variations within the given volume. The TT residuals $\mathrm{TR}_{i j}$ (at the $i$ th station for the $j$ th event) include effects of origin time uncertainty, hypocenter location errors and velocity perturbations outside the study area. These effects are eliminated while subtracting some reference residual $\mathrm{TR}_{j}$, and the relative residuals $\mathrm{RTR}_{i j}$, which are used in the inversion, are calculated.

To invert the data set, the ACH inversion method by Aki et al. (1977), which later was developed by Evans and Achauer (1993), was used. According to Evans and Achauer (1993), the problem can be linearized through block parameterization, disregarding refraction by the slowness perturbations:

$\boldsymbol{b}=\mathbf{G} \boldsymbol{m}$,

where $\boldsymbol{b}$ is a vector derived from the relative TT residuals $\mathrm{RTR}_{i j}, \boldsymbol{m}$ is a vector of perturbations of slowness, and $\mathbf{G}$ is a matrix derived from unperturbed TT of a ray $i j$ in block $k$. To estimate $\boldsymbol{m}$, the damped least squares can be used, and the basic inversion equation for the TELINV code can be written as

$\boldsymbol{m}^{\text {est }}=\left(\mathbf{G}^{\mathrm{T}} \mathbf{W}_{\mathrm{D}} \mathbf{G}+\varepsilon^{2} \mathbf{W}_{\mathrm{M}}\right)^{-1} \mathbf{G}^{\mathrm{T}} \mathbf{W}_{\mathrm{D}} \boldsymbol{b}$,

where $\boldsymbol{m}^{\text {est }}$ are estimated model parameters, $\mathbf{W}_{\mathrm{D}}$ is a weighting matrix of the data, $\varepsilon^{2}$ is a damping factor, and $\mathbf{W}_{M}$ is the smoothing matrix of the model. The abilities of the ray geometry and model parameter grid to resolve the velocity perturbations can be estimated by a resolution matrix (Menke, 1984):

$\mathbf{R}=\left(\mathbf{G}^{\mathrm{T}} \mathbf{W}_{\mathrm{D}} \mathbf{G}+\varepsilon^{2} \mathbf{W}_{\mathrm{M}}\right)^{-1} \mathbf{G}^{\mathrm{T}} \mathbf{W}_{\mathrm{D}} \mathbf{G}$.
The code is an iterative process where each iteration involves a complete one-step inversion, including both ray tracing and model estimations. Iterations stop when the model ceases to change significantly and the root-mean-square (RMS) difference between predicted and observed TT residuals is comparable to data variance. The data is a relative measure, thus, one can estimate only relative perturbations to the used reference model.

The ray tracing is crucial in teleseismic tomography. A ray path is determined through a model, i.e., which nodes the ray crosses and how much time it spends at each node. An algorithm produces the theoretical TT that are used in computing the relative residual arrival time data. In our study, the 3-D ray tracing algorithm of Steck and Prothero (1991) was used. The procedure performs a simplex search for the fastest path of a planar wavefront to a point at the surface. In this procedure, the departure point of a ray from the plane wave is not fixed, but determined by the algorithm itself. It assumes that the ray bending and distortions are caused by heterogeneities along their paths (Weiland et al., 1995; Sandoval, 2002).

\section{Model parameterization}

Our study area is shown in Fig. 2. The model parameterization must be fine enough in order to capture the structure that can be resolved. Regarding the seismic signal frequency and spacing between the seismic stations, we set a spacing of $50 \mathrm{~km}$ between the grid nodes in horizontal directions. The 1D IASP91 velocity model (Kennett and Engdahl, 1991) was used to parameterize the reference 3-D velocity model with 16 layers of constant velocities (i.e., all nodes in one layer were assigned the same values) down to $700 \mathrm{~km}$. We set the inverted layers (between 70 and $350 \mathrm{~km}$ ) every $30 \mathrm{~km}$ from 90 to $300 \mathrm{~km}$ and two more layers at 70 and $350 \mathrm{~km}$ depth, while below, we set two non-inverted layers for the stability of the inversion, and four non-inverted layers above in the Earth's crust (from surfaces down to $50 \mathrm{~km}$ ). Every layer of the compiled initial velocity model was assigned a constant value of the seismic velocities from the IASP91 velocity model.

We performed a thorough analysis in order to select the optimal inversion parameters. The damping parameter determines how much noise present in the data is mapped in the resolved model. Underestimation of damping would result in noise fitting while overestimation would reduce lateral velocity variations. The damping value was determined while running inversions with different values of damping and investigating trade-off between the data variance and model variance (Fig. 4). From the curve one may find that the optimal value for damping is 80 . However, here we present results obtained using a damping value of 120 , which is more conservative and obviates the velocity anomalies of shorter wavelengths compared to the results obtained using a damping of 80 . As we aim to resolve regional-scale velocity variations in 


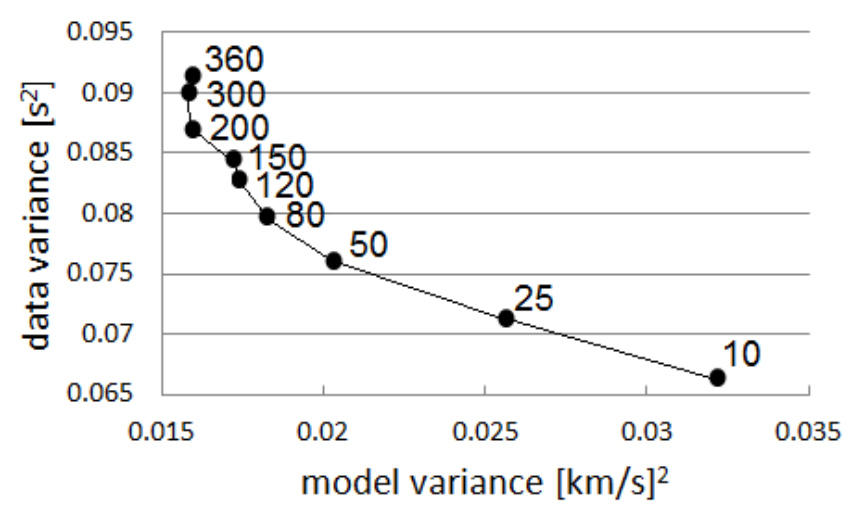

Figure 4. Trade-off between the data variance and model variance obtained with different damping values from 10 to 360 . The presented results were obtained using a damping value of 120 .

the study area, the larger damping value was used. We also found that three iterations are enough for inversion, because for higher number of iterations, the model and the RMS error change insignificantly.

\section{Crustal travel time corrections}

As discussed previously (see Sect. 1.2), the structure of the crust in the study area varies significantly, as well as the thickness of the sedimentary cover, which is up to about $20 \mathrm{~km}$ in the Polish Basin. In order to obtain the upper mantle structure, it is important to remove the effects, which are created by the Earth's crust, from the inversion results. The crustal TT corrections for individual seismic stations were compiled as follows:

$\mathrm{TT}_{\text {model }}-\mathrm{TT}_{\text {iasp }}=\mathrm{TT}_{\text {diff }}$,

where $\mathrm{TT}_{\text {model }}$ is $\mathrm{TT}$ through the crustal velocity model, $\mathrm{TT}_{\text {iasp }}$ is TT through the IASP91 velocity model, and $\mathrm{TT}_{\text {diff }}$ is TT difference. We used two sets of the crustal TT corrections: (1) the first set was compiled using the EuCRUST07 (Tesauro et al., 2008) 3-D crustal model for Europe with model grid of $1^{\circ} \times 1^{\circ} ;(2)$ the second set was compiled using the precise 3-D crustal model for Poland (Majdański, 2012) with model grid of $0.3^{\circ}$ of latitude and $0.5^{\circ}$ of longitude, and results of some DSS profiles. The crustal model by Majdanski (2012) was compiled using all available information from the DSS profiles carried out around Poland. However, outside the crustal model there is not much data to be used, thus, the territories not covered by the model by Majdański (2012) were assigned with constant values that were estimated using the interpreted results (full velocity profiles) below shot point SP9 in the EUROBRIDGE'95 profile and shot point SP2 in the CELEBRATION09 profile. The value obtained from the EUROBRIDGE'95 profile was used for the stations deployed in Lithuania, and value obtained from the CELEBRATION09 profile was used for the stations deployed in
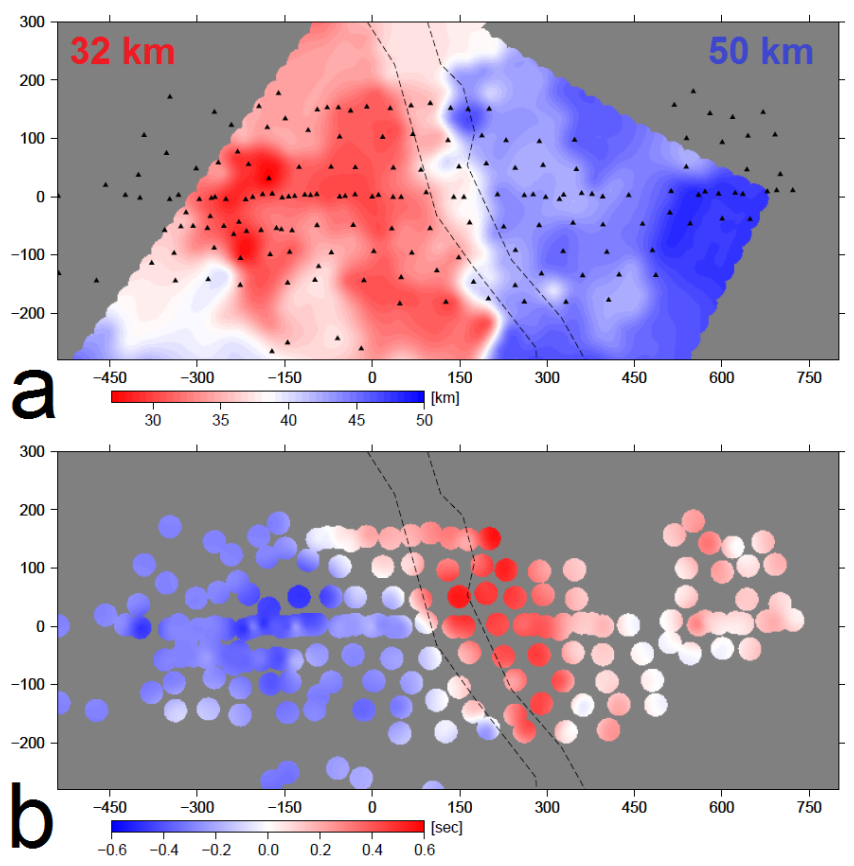

Figure 5. (a) Moho map of the precise 3-D crustal model by Majdański (2012), which was used to estimate the crustal TT corrections. The Moho depth for the areas outside the model was defined using results of some DSS projects: the area to the east was assigned $50 \mathrm{~km}$ and, to the west $32 \mathrm{~km}$. (b) Estimated crustal TT corrections in the individual seismic stations. The values are expressed in seconds with respect to the IASP91 velocity model.

Germany and the Czech Republic (the constant depths of the Moho boundary of $50 \mathrm{~km}$ and $32 \mathrm{~km}$, respectively, were assigned as well) (Fig. 5a). The crustal TT corrections were calculated assuming the vertical ray propagation in the crust. Regarding the incidence angles in our data set, the assumed vertical propagation in the crust causes $<2 \%$ shortening of the raypaths, thus, the effect in the results on velocity amplitudes is negligible.

In order to estimate the effect of the crustal TT corrections on the velocity amplitudes, we performed inversion with the real data set without (Fig. 6a) and with the crustal corrections applied (Fig. 6b, c). In the inversion results with the EuCRUST-07 model (Fig. 6b), we observe a "high-lowhigh" distribution of velocity variations in the study area, and artificially high signal amplitudes of up to $\pm 12 \%$, especially around the TESZ, where the thickness of the sediments is significantly larger compared to the surroundings. This result is not consistent with our knowledge about the possible geological conditions in the study area (see Sect. 1.2), and obviously it is not what we may expect from a decent set of crustal TT corrections. Thus, we concluded that this set of the crustal corrections is too robust and is not applicable in our study.

The inversion results (Fig. 6c) obtained with the second set of crustal TT corrections (Fig. 5b) based on the crustal 

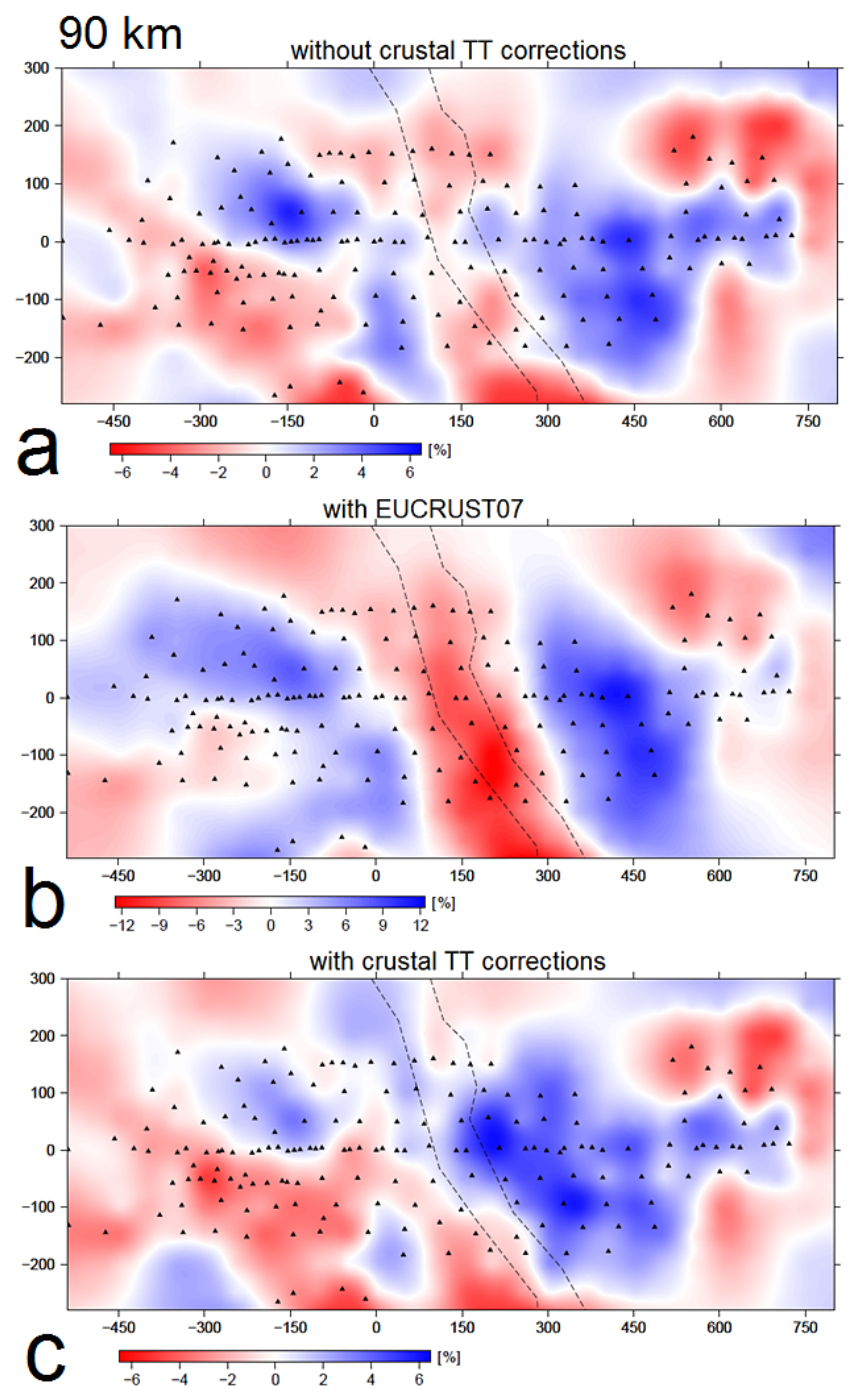

Figure 6. Horizontal slices at a depth of $90 \mathrm{~km}$ of the inversion results (a) without crustal TT corrections, (b) with the EuCRUST07 model, and (c) with crustal TT corrections compiled using the model by Majdański (2012) and the result of some DSS projects. Triangles indicate seismic stations. Dashed lines indicate the TESZ.

model by Majdański (2012) and some DSS studies do not reproduce the shapes of the thick sediments in the TESZ, as is obvious in Fig. 6b, but show two distinct structures on both sides of the TESZ: the higher velocities to the east and lower velocities to the west. Compared to the results obtained without (Fig. 6a) and with (Fig. 6c) the crustal TT corrections, one may find quite similar patterns of velocity distribution; however, there are some significant differences. As the color scale is the same in both Fig. 6a and c, one may notice somehow reduced amplitudes of the velocity perturbations in Fig. 6c. As expected, the negative amplitudes are reduced in the northeastern part of the study area (western Lithuania), where the sedimentary basin up to $2 \mathrm{~km}$ thick is present, and in the northern and central part of the TESZ, the negative am- plitudes turn positive, which indicates significant correction for the thick sedimentary cover. Moreover, one may indicate reduced positive anomalies in the western part of the study area. We observe no obvious artifacts in the results, which are quite consistent with what we expect from the previous studies (see Sect. 1.2). Thus, we concluded that this set of the crustal TT corrections is reasonable, and it was used in our study. However, the introduced crustal TT corrections bring in some additional effects to the results. We observe this effect down to about $180 \mathrm{~km}$, while in the deeper parts, it is negligible. The effects from the crustal TT corrections were also reported in other studies; e.g., Sandoval et al. (2003) observe the effect down to about $200 \mathrm{~km}$.

\section{Resolution and synthetic tests}

To estimate the resolution of the inversion results, we use the hit matrix and the checkerboard test. The two methods combined enable us to define the resolution fairly well. The hit matrix is based on calculation of the number of rays that transverse a particular cell. The inversion with the synthetic checkerboard model shows which parts of the target area can be and cannot be resolved with the same configuration as the observed data set. In our study, we compiled the synthetic velocity model of the checkerboard structure with blocks of $200 \mathrm{~km}$ in horizontal directions and four layers thick with a $\pm 4 \%$ velocity difference with respect to the IASP91 velocity model (Fig. 7a). The synthetic data set was compiled by adding Gaussian-distributed perturbations (up to $\pm 0.4 \mathrm{~s}$ ) to all observed TT. The inversion results obtained with the synthetic data set show a reasonably well-resolved checkerboard-type structure (Fig. 7b). However, in the vertical slices in Fig. 7b, we observe the vertical smearing dipping to the east, which is most likely due to the majority of rays coming from the regions located to the east of the study area (Fig. 3). Moreover, the synthetic structure in the western part is better resolved than in the eastern part (Fig. 7b), due to the larger number of top-quality picks in the data of the stations deployed to the west of the TESZ. The further estimate of the resolution is derived from the diagonal elements of the resolution matrix (Fig. 8), which provides a relative measure of the resolution: the low values show areas of low resolution and the high values show areas of high resolution. The inversion was performed using the larger damping value (i.e., 120), but we still obtain quite large velocity perturbations (up to $6.5 \%$ ) that are related to the small values of the diagonal elements of the resolution matrix observed in Fig. 8, which suggests quite sparse data coverage and considerable vertical smearing in some parts of the study area, which is consistent with the results of the checkerboard test (Fig. 7b). We will discuss the resolution of the areas that are directly beneath the seismic array because, outside the array, we have no ray coverage and, thus, zero resolution. Fig. 8 indicates the highest resolution (dark color) in the southwestern part 

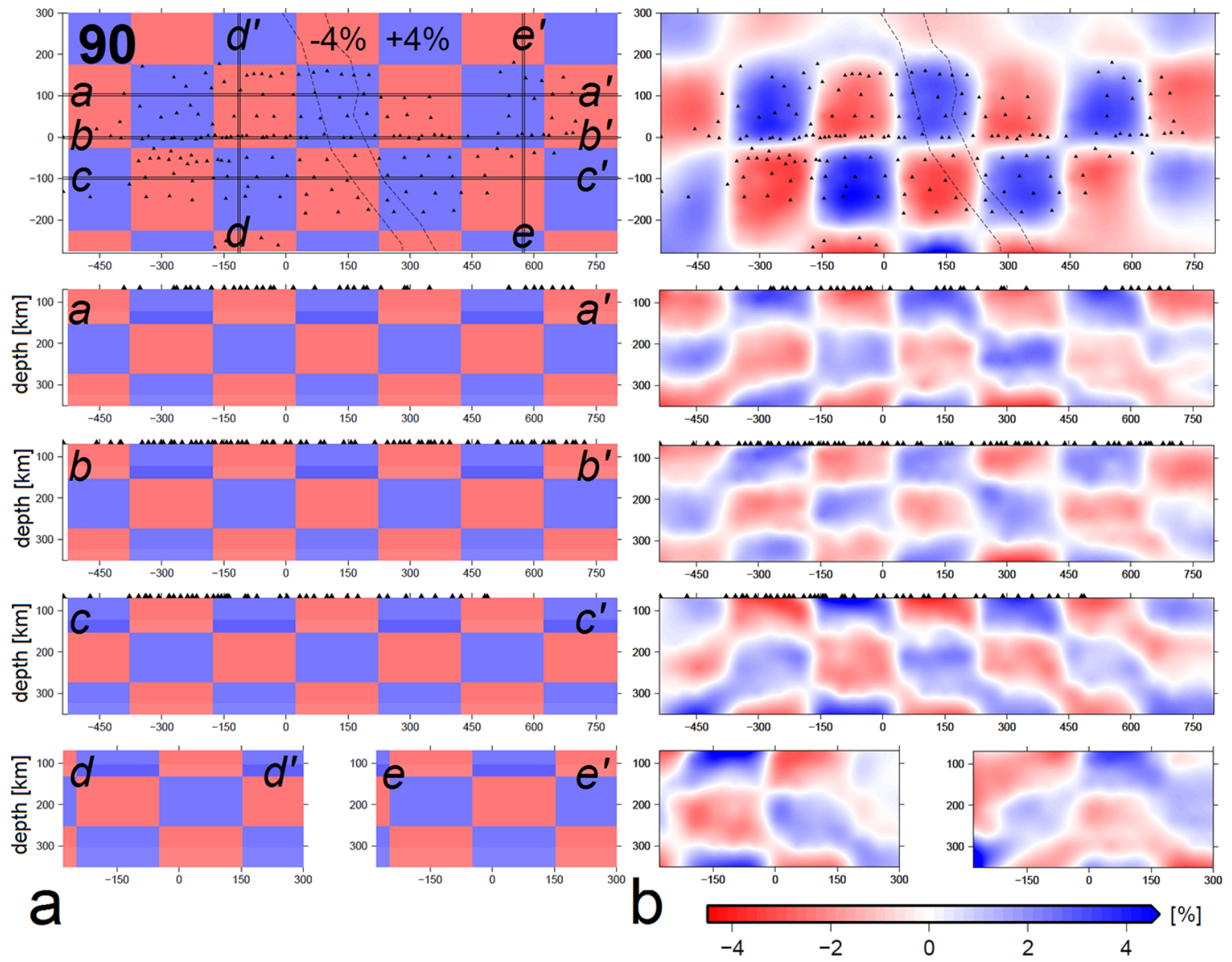

Figure 7. Checkerboard test. Horizontal slice at a depth of $90 \mathrm{~km}$ and vertical slices along the depicted transects. (a) Initial velocity model. (b) Inversion results with the synthetic data set. Triangles mark the seismic stations. Dashed lines indicate the position of the TESZ.

of the study area, from the top of the inverted layers down to about $250 \mathrm{~km}$, which coincides with areas of the densest station coverage (i.e., the larger number of picks in the data set) and good crossing of the seismic ray paths. In the rest of the areas below the seismic array, we obtain a fair resolution (lighter grey). On the vertical slice along the main transect (Fig. 8), we observe a "dark color" below $300 \mathrm{~km}$, which is an artifact from the inversion and does not indicate good resolution, because at these depths the rays do not cross.

We also performed a synthetic test with a robust "geologically possible" velocity model in order to find out whether our data set with current station configuration is capable to resolve the introduced large scale structures. We also aim to test whether the obtained inversion result would be similar to the one obtained with the real data set, because this could invoke some reasonable speculations for interpretation. Based on the previous geophysical and petrophysical studies (Wilde-Piórko et al., 2010; Griffin et al., 2003), we com- piled a synthetic 3-D velocity model with geologically possible structure. The main features of the synthetic "geological" velocity model (Fig. 9a) are: (1) the lower and the higher seismic velocities to the west and to the east from the TESZ, respectively, (2) the shape of the LAB of a ramp type dipping to the northeasterly direction, and (3) the deep cratonic roots for the EEC (in the northeastern part of the study area). Small TT perturbations were added to the synthetic TT, as for the checkerboard test. The inversion result obtained with the synthetic data set (Fig. 9b) shows the lower and the higher velocity areas to the west and to the east from the TESZ, respectively. In the results we also observe the clear ramp shape of the LAB and the higher velocity anomaly at the bottom of the velocity model in the northeastern part of the study area (Fig. 9b). In the results, one may also notice that we do not resolve the same average velocities with respect to the input velocity model, however, the total ratio of positive and negative amplitudes of perturbations is similar in both the 


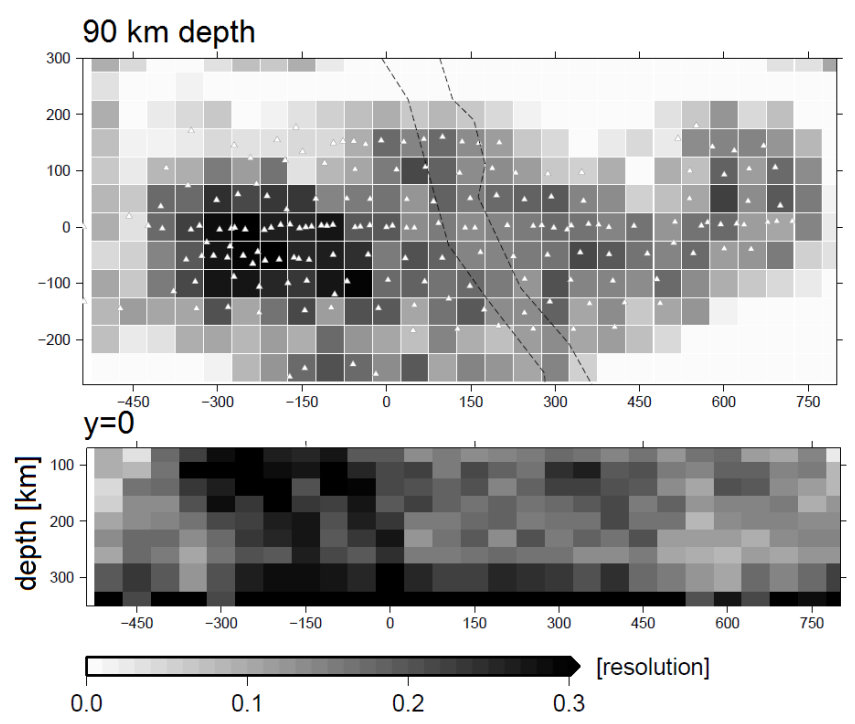

Figure 8. Diagonal elements of the resolution matrix in horizontal slice at $90 \mathrm{~km}$ depth and vertical slice along the main transect of the study area. The low and high values of resolution indicate poorly resolved and well-resolved areas, respectively. Triangles mark seismic stations. Dashed lines indicate the TESZ.

reference model and the inversion results. This implies that the resolved negative amplitudes could be considered as neutral or slightly positive instead.

\section{Results and discussion}

As shown by numerous seismic studies (e.g., KnapmeyerEndrun et al., 2013b), the LAB in Precambrian cratonic areas is not easily detected by seismic methods and can be misinterpreted with the so-called Mid-Lithospheric Boundary (MLB). The nature of the latter is still not completely understood. However, the seismic LAB can be detected beneath the younger areas and traced across boundaries of the cratons in the passive seismic experiments that sample both the cratonic and non-cratonic lithospheres. In our study, we used the data of such a passive seismic experiment and performed inversions with the compiled data set of top-quality $\mathrm{P}$ wave arrivals. We resolved the structure of the upper mantle from $70 \mathrm{~km}$ down to $350 \mathrm{~km}$ in the study area. The obtained model of $\mathrm{P}$ wave velocity variations can be used to estimate the seismic LAB and the lithosphere thickness around the TESZ. In our study, we embrace the definition of the seismic LAB as a transition between the higher and lower seismic velocities, which was discussed previously. The obtained results, of course, depend on the reference velocity model; thus, to be on the conservative side, we used the well-known IASP91 velocity model and obtained results with respect to this reference model.

In our results (Fig. 9c) we observe amplitudes of velocity variations up to $\pm 6.5 \%$ with respect to the IASP91 velocity model, which is definitely too high to be explained by the geological-tectonic conditions only. In teleseismic tomography many factors contribute to the observed signal (velocity) amplitudes, such as damping value, implementation of the crustal TT corrections (about $1 \%$ of the observed velocity contrast), temperature variations (about $1 \%$ ) and anisotropy in the study area, and distortions on the full raypaths outside the velocity model (which varies from region to region). Moreover, the used TELINV code implements the "flat-earth" model, which affects the apparent seismic velocities. Regarding the size of our velocity model and the incidence angles in our data set, the discrepancy due to the used "flat-earth" model is about $1.5 \%$ of the observed amplitudes of velocity variations. Thus, taking into account all the above mentioned causes we should consider the amplitudes of velocity variations not $\pm 6.5 \%$, but close to about $\pm 3 \%$.

The inversion results with our real data set show the higher $P$ wave velocity values with respect to the IASP91 velocity model beneath the EEC and lower ones beneath western Europe, while the TESZ appears as a transitional complex tectonic structure with significant velocity perturbations in longitudinal and transversal directions (Fig. 9c). This general finding coincides with the results by Koulakov et al. (2009) who reported the sharp transition along the TESZ from the negative amplitudes, characterizing the young tectonic features of central-western Europe, to positive ones beneath the old EEC. Moreover, a sharp transition from low to high shear-wave velocities between the Phanerozoic Europe and EEC, respectively, was observed from waveform inversion of both body and surface waves by Zielhuis and Nolet (1994). We also indicate that the LAB is more distinct beneath the Phanerozoic part of Europe than beneath the Precambrian part, which coincides with the results by Plomerova and Babuska (2010) and Knapmeyer-Endrun et al. (2013b).

To the east of the TESZ the pronounced high-velocity structure in the upper mantle is observed beneath Poland (Fig. 9c). The observed velocity perturbations down to about $120 \mathrm{~km}$ beneath Poland are about 2 to $3 \%$ higher with respect to the IASP91 velocity model, while going deeper the variations are slightly smaller, which most likely indicates some effects due to the applied crustal TT corrections. The higher velocity values in this area are observed down to about $200 \mathrm{~km}$, which coincides well with the studies by WildePiórko et al. (2010), Majorowicz et al. (2003) and Koulakov et al. (2009). Legendre et al. (2012) found the highest velocity values in the mantle of the EEC at about $150 \mathrm{~km}$ depth. Further to the northeast of the TESZ, the high-velocity area goes deeper, and beneath the territory of Lithuania, we find the thickest lithosphere of about $300 \mathrm{~km}$ or more (Fig. 9c). Due to vertical smearing (Fig. 7b), which is intrinsic to all tomography inversions, the observed higher velocity area associated with the deep cratonic roots could be extended to the layers deeper than it really is, however, our result is in a good agreement with other observations - the obtained value of thickness of the lithosphere beneath the EEC is about $50 \mathrm{~km}$ 

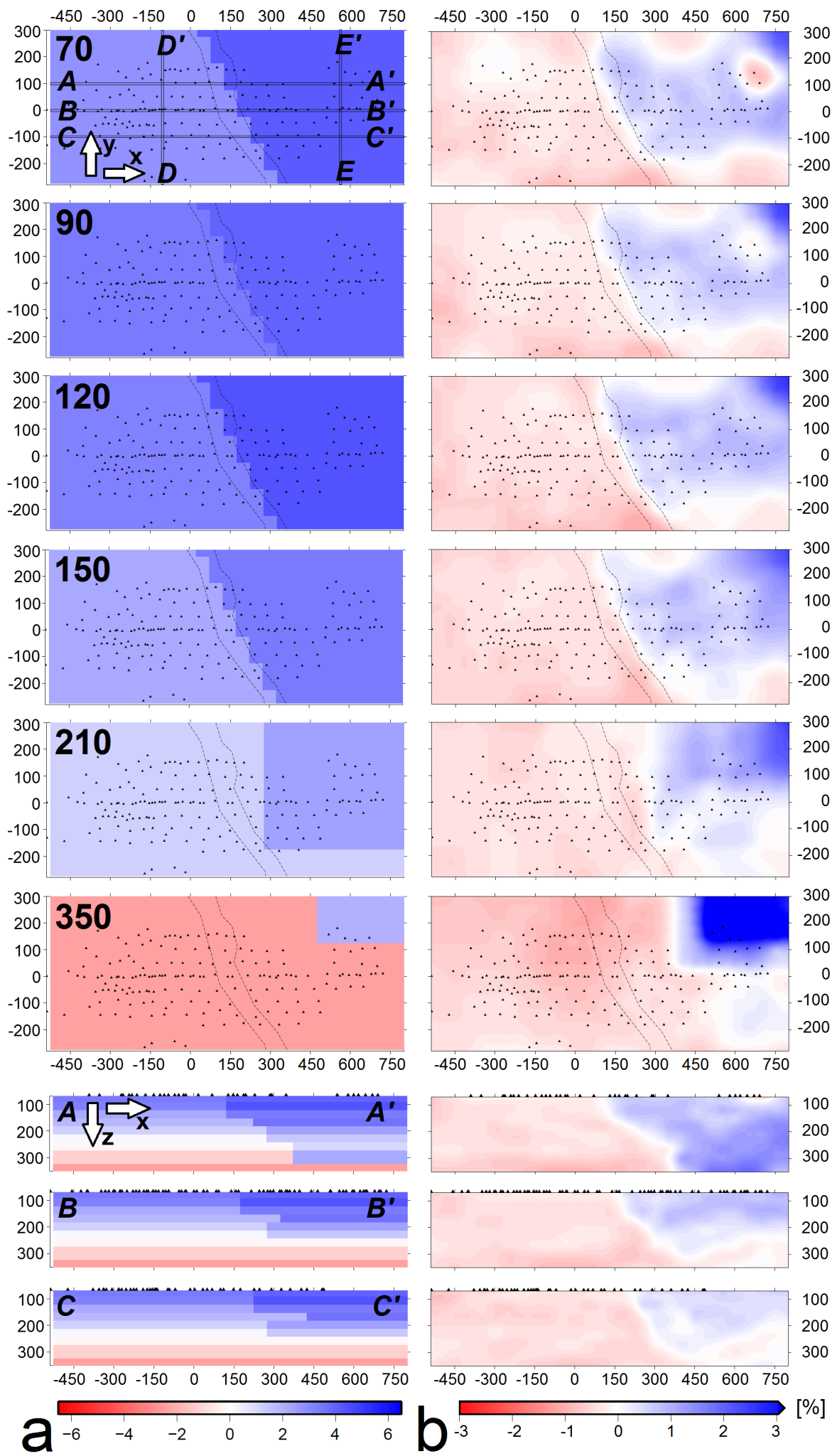

Figure 9. 

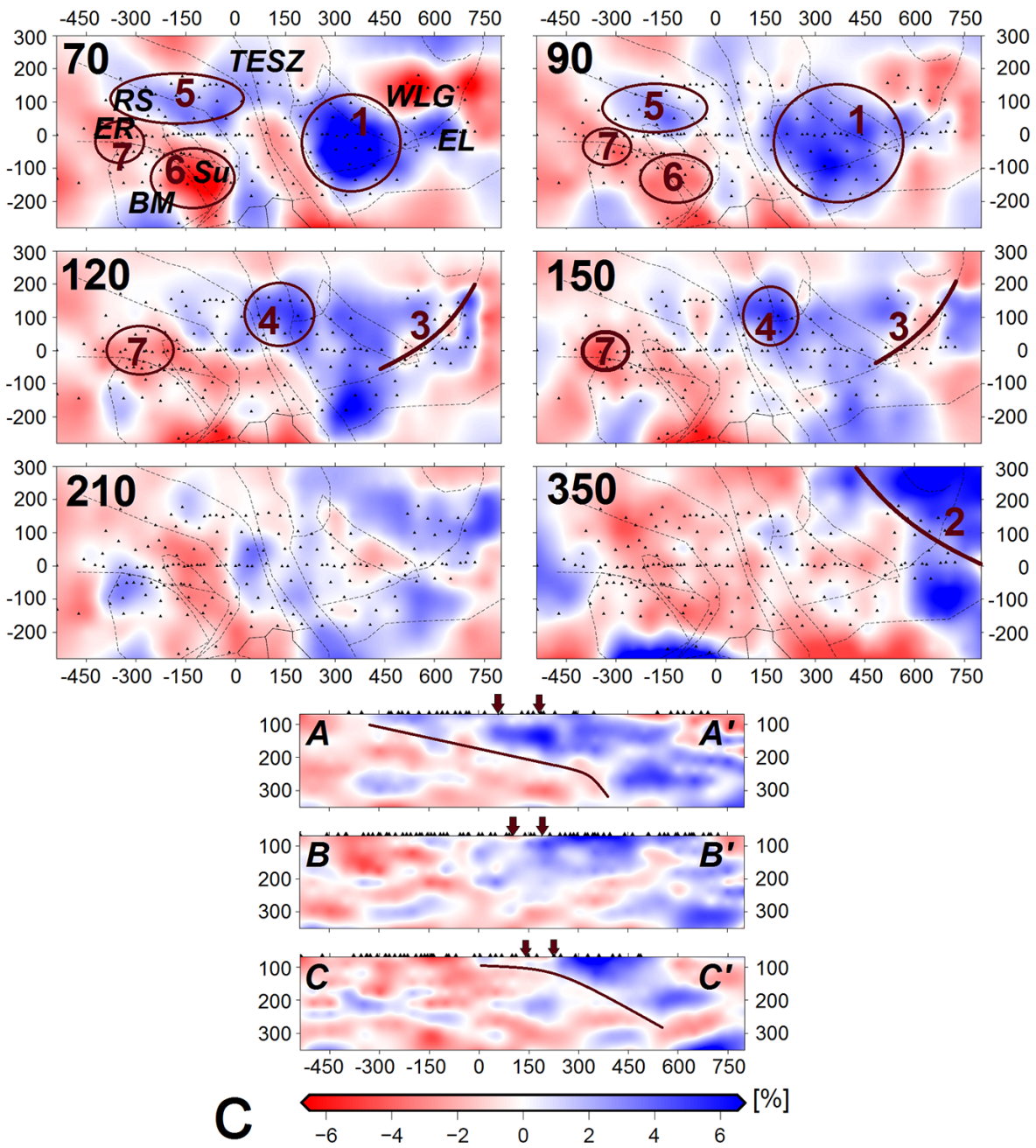

Figure 9. $P$ wave velocity perturbations in horizontal slices at indicated depths $(\mathrm{km})$ and vertical slices parallel to the main transect of the study area. Results obtained with the synthetic "geological" model: (a) input velocity model, and (b) inversion results. (c) Results obtained with the field data set. Triangles mark seismic stations. $x, y$ and $z$ indicate longitude, latitude and depth $(\mathrm{km})$, respectively, in a local Cartesian coordinate system. Dashed lines on horizontal slices indicate boundaries of tectonic units (see Fig. 1b). Numbered areas mark the discussed interpreted structures: (1) high-velocity area beneath Poland (craton); (2) deep cratonic roots extending to at least $300 \mathrm{~km}$ or more beneath Lithuania; (3) paleosubduction boundary between the WLG and the EL; (4) high-velocity area beneath northern Poland; (5) higher velocity area along the Rheic Suture; (6) lower velocity area beneath the Sudetes Mountains and the Bohemian Massif; (7) low-velocity area beneath the Eger Rift. Solid lines on vertical slices show the interpreted seismic LAB; and brown arrows indicate the TESZ.

larger compared to the global tomography results obtained by Artemieva et al. (2006), but coincides well with results obtained from P- and S-wave tomography by Koulakov et al. (2009) who find the $\mathrm{P}$ wave velocities up to $2 \%$ higher extending to at least $300 \mathrm{~km}$ beneath Lithuania. Thick lithosphere extending to at least $250 \mathrm{~km}$ depth is also found beneath the central part of the Fennoscandian Shield (Sandoval et al., 2004), but there are found no indications of the seismic LAB anywhere within $300 \mathrm{~km}$ beneath the EEC (Bruneton et al., 2004; Geissler et al., 2010; Legendre et al., 2012). Our study does not show the seismic LAB beneath the EEC either. The study of $S$ receiver functions by Knapmeyer-Endrun et al. (2013b) indicates a negative conversion that could be re- lated to a velocity decrease at $190 \mathrm{~km}$ to $230 \mathrm{~km}$ depth, which is in agreement with the depth estimates for the cratonic LAB; however, the conversion was not observed in all analyzed seismic stations in the EEC. Thus, the authors suggest that the stations might imply spatial variations in the sharpness of the corresponding velocity change.

In the northeastern part of the study area beneath Lithuania, at depths of $120-150 \mathrm{~km}$, we find the lower velocities compared to the surroundings following the MLSZ (Fig. 9c) - the predicted paleosubduction zone between the WLG and EL (Motuza, 2004; Motuza, 2005; Motuza and Staškus, 2009). Our results (Fig. 10b) also indicate a slope of higher velocities dipping to the north, which agrees with the model 


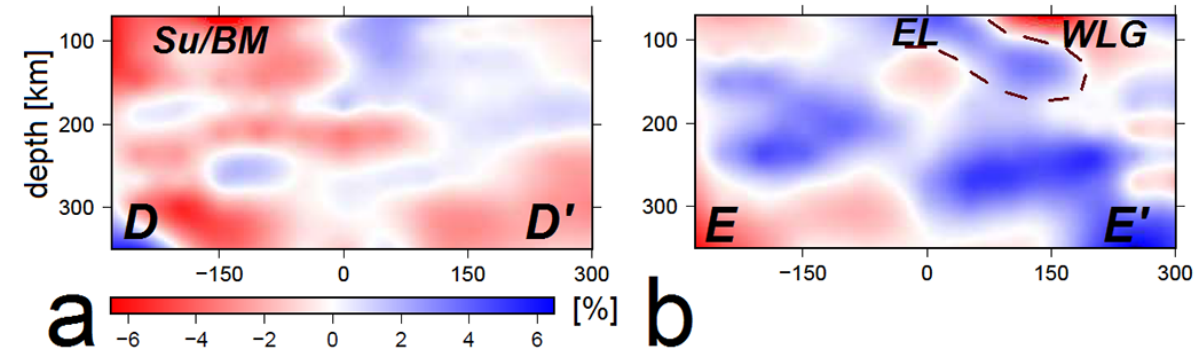

Figure 10. $P$ wave velocity perturbations in vertical slices $\mathrm{DD}^{\prime}$ and $\mathrm{EE}^{\prime}$ transverse to the main transect (see Fig. 9a). (a) Low velocities are observed in the western part of the Bohemian Massif (BM) and the Sudetes Mountains (Su) from $70 \mathrm{~km}$. (b) Dashed line indicates a possibly resolved paleosubduction zone under Lithuania between the WLG and the EL.

proposed by Motuza and Staškus (2009) that the EL subducted under the WLG. The anomaly is relatively small, thus its existence is questionable; however, the ray coverage in this part of the study area is reasonable (Fig. 8). We infer that this feature may indicate a slab of "frozen" paleosubduction, while the lower velocities observed below the slab along the predicted paleosubduction edge could be related to an increase in temperature.

We find an area of the higher velocities in the lithospheric mantle down to about $180 \mathrm{~km}$ in the northern part of the TESZ (northern Poland) (Fig. 9c). KnapmeyerEndrun et al. (2013a) observe an increase in TT of Ps conversions across the mantle transition zone that could be caused either by a temperature reduction or an increase in water content in this mantle region. As we observe the higher velocities in this part, we propose that this anomaly could be related to thermal regime and temperature reduction. In general, the upper mantle of the northern TESZ is more of a cratonic type, while going to the south, the seismic velocities are lower.

Our results indicate the dominating negative velocity amplitudes to the west of the TESZ almost everywhere down to $350 \mathrm{~km}$, except in the territory of northern Poland and Germany along the Rheic Suture, where we find the higher velocity anomaly down to about $90-100 \mathrm{~km}$, while closer to the TESZ, the LAB is observed at a depth of about $120 \mathrm{~km}$ (Fig. 9c). The result is consistent with results obtained by Knapmeyer-Endrun et al. (2013b) and WildePiorko et al. (2010), who indicate the average seismic lithosphere thickness of about $90 \mathrm{~km}$, and associate the uplift of the LAB beneath western Europe and the TESZ with partial melting of the upper mantle due to thermal conditions (Wilde-Piorko et al., 2010). Moreover, the studies of Shomali et al. (2006) and Gregersen et al. (2010) carried out using data of the TOR 1996-1997 passive seismic project indicate a lithosphere thickness of about $100 \mathrm{~km}$ in northern Germany, which coincides well with our results for this territory. The depth of the LAB of about $100 \mathrm{~km}$ is a characteristic common to the Phanerozoic regions (Plomerova et al., 2002).

The observation of the lower velocity values (Fig. 9c) with respect to the IASP91 velocity model to the west of the TESZ coincides with results by Koulakov et al. (2009) who report the negative anomalies up to $4 \%$ for this area. In our results the large lower velocity area of about -2 to $-3 \%$ with respect to the IASP91 velocity model is observed beneath the Bohemian Massif and the rift systems in central Europe (Fig. 9c). The lithosphere thinning of 80-90 km beneath the Armorican terrains of Saxothuringian, Tepla-Barrandian and Moldanubian is reported in studies by Babuška and Plomerova (2001). Karousova et al. (2013) find an extensive lowvelocity heterogeneity in the upper mantle beneath the Bohemian Massif, while Koulakov et al. (2009) report the broad negative zone ( -1 to $-3 \%)$ beneath the Central Rift System and the Bohemian Massif at depths from 100 to $200 \mathrm{~km}$. In our results we find the largest negative signal amplitudes under the northeastern part of the Bohemian Massif and the Sudetes Mountains from a depth of at least $70 \mathrm{~km}$ (Figs. 9c, 10a). Moreover, our results indicate the lower velocity anomaly under the Eger Rift (Fig. 9c). Although the Eger Rift is a relatively small structure, our data set is sufficient to resolve it, thus, we indicate the lower velocities from $70 \mathrm{~km}$ down to at least $180 \mathrm{~km}$ beneath it. This result is in a good agreement with results by Karousova et al. (2013) who indicate the most distinct low-velocity perturbations along the Eger Rift down to about $200 \mathrm{~km}$, and Koulakov et al. (2009) who observe the low-velocity zone $(-2 \%)$ in this area between about 80 and $250 \mathrm{~km}$. Plomerova et al. (2007) interpreted the broad low-velocity anomaly beneath the Eger Rift as an uplift of the LAB.

The asthenosphere on the western edge and on the eastern edge of the TESZ is at depths of about $150 \mathrm{~km}$ and $180 \mathrm{~km}$, respectively. Moreover, the structure of the TESZ varies significantly, going from north to south (Fig. 9c). In the studies of Legendre et al. (2012), it is found that the mantle lithosphere beneath the TESZ shows moderately high velocities, and is of an intermediate character between that of the cratonic lithosphere and the thin lithosphere of central Europe. The studies carried out around the TESZ indicated a sharp discontinuity along the TESZ, but provided no strong evidence of the shape of the LAB beneath it due to a lack of resolution (discussed by Knapmeyer-Endrun et al., 2013a). As 
we used a dense network of the seismic stations (Fig. 2) (with an average spacing of $60 \mathrm{~km}$ and a spacing of $20 \mathrm{~km}$ along the main PASSEQ transect), we are able to resolve the shape of the LAB with higher precision. In the results (Fig. 9c), we indicate that, in the northern part of the study area, the higher velocities (which are associated with the seismic LAB) are observed deeper going in the northeasterly direction, which shows the ramp shape of the LAB. The angle of the deepening of the LAB is about 30 degrees. In the northern part of the TESZ, we do not recognize any separate structures or clear contact, which could be related to the different tectonic settings of Phanerozoic and Proterozoic Europe but, further to the south, we may refer to a sharp and steep contact on the eastern edge of the TESZ (Fig. 9c). In our "geological" synthetic model, we introduced and reasonably resolved the LAB ramp type dipping in the northeasterly direction as well (Fig. 9a, b), which is somehow similar to the results obtained with the real data set (Fig. 9c). Gregersen et al. (2010) compared results of different studies performed using the data of the TOR project and concluded that the transition between the two tectonic settings on both sides of the STZ is sharp and steep, with a weak tendency to the northeasterly slope. We indicate from our results (Fig. 9c) that, further to the south, the LAB is shallower, and its shape changes most probably due to younger tectonic settings (i.e., the Carpathian Mountains) in the region.

\section{Conclusions}

- The observed higher $P$ wave velocity values to the east of the TESZ correspond to the older EEC and the lower ones to the west of the TESZ correspond to younger western Europe. The TESZ is resolved as a complex structure with intermediate characteristics between those of the EEC and western Europe.

- We indicate that the seismic LAB is more distinct beneath the Phanerozoic part of Europe than beneath the Precambrian part. The lower velocity anomalies from $70 \mathrm{~km}$ are observed under the Bohemian Massif, the Sudetes Mountains and the Eger Rift, while further north, beneath the Variscides, the depths of the LAB are about $100-120 \mathrm{~km}$. Our study does not show the seismic LAB beneath the EEC, but beneath Lithuania we find the thickest lithosphere of about $300 \mathrm{~km}$ or more. In the TESZ, the asthenosphere is at depths of $150-180 \mathrm{~km}$, which is an intermediate value between that of the EEC and western Europe.
- In the northern part of the TESZ, the upper mantle is more of a cratonic type. We infer that the LAB in the northern part of the study area is of a ramp type dipping to the northeasterly direction at an angle of about 30 degrees. Under the northern part of the TESZ, we do not recognize any contact between the Phanerozoic and Proterozoic parts of Europe, but, further to the south, we may refer to a sharp and steep contact on the eastern edge of the TESZ. Going to the south, the shape of a LAB beneath TESZ is changing, and its depth is shallower, most likely due to younger tectonic processes.

- Beneath Lithuania at depths of 120-150 km, we observe the low-velocity area that follows the boundary of the proposed paleosubduction zone between the EL and the WLG tectonic units. 


\section{Appendix A}

Table A1. List of 101 teleseismic EQs used in this study.

\begin{tabular}{|c|c|c|c|c|c|c|c|}
\hline Year & Month & Day & Time UTC & Lat. & Long. & Depth & $M$ \\
\hline 2006 & 6 & 18 & $18: 28: 00$ & 32.9995 & -39.7009 & 8.6 & 6.0 \\
\hline 2006 & 6 & 22 & $10: 53: 11$ & 45.3023 & 149.4132 & 104.3 & 6.0 \\
\hline 2006 & 6 & 27 & 18:07:21 & 6.4781 & 92.7356 & 25.8 & 6.3 \\
\hline 2006 & 6 & 27 & $2: 39: 33$ & 52.1552 & 176.1572 & 28.3 & 6.2 \\
\hline 2006 & 6 & 28 & 21:02:09 & 26.8361 & 55.806 & 15.1 & 5.8 \\
\hline 2006 & 7 & 6 & $3: 57: 52$ & 39.0233 & 71.7719 & 23.7 & 5.8 \\
\hline 2006 & 7 & 8 & $20: 39: 57$ & 51.1889 & -179.264 & 3.2 & 6.6 \\
\hline 2006 & 7 & 10 & $7: 21: 36$ & -11.5727 & -13.4176 & 10 & 5.5 \\
\hline 2006 & 7 & 12 & $14: 44: 44$ & -8.5692 & 67.8158 & 10 & 5.7 \\
\hline 2006 & 7 & 27 & $11: 16: 40$ & 1.7244 & 97.1295 & 30 & 6.3 \\
\hline 2006 & 7 & 29 & $19: 53: 41$ & 23.5288 & -63.876 & 8.5 & 5.8 \\
\hline 2006 & 8 & 6 & $14: 26: 17$ & 37.4091 & 74.7119 & 4.9 & 5.6 \\
\hline 2006 & 8 & 6 & $18: 16: 39$ & 26.2558 & 143.9864 & 23 & 5.9 \\
\hline 2006 & 8 & 11 & $14: 30: 39$ & 18.4706 & -101.135 & 58.4 & 6.1 \\
\hline 2006 & 8 & 16 & $18: 38: 58$ & -28.8283 & 61.7726 & 10 & 5.9 \\
\hline 2006 & 8 & 24 & $21: 50: 36$ & 51.0679 & 157.5354 & 53.5 & 6.5 \\
\hline 2006 & 9 & 1 & $12: 04: 21$ & 53.9609 & -166.361 & 75.6 & 5.9 \\
\hline 2006 & 9 & 10 & $14: 56: 06$ & 26.39 & -86.5804 & 10 & 5.9 \\
\hline 2006 & 9 & 24 & $22: 56: 21$ & -17.6967 & 41.8104 & 17.2 & 5.7 \\
\hline 2006 & 9 & 29 & $13: 08: 24$ & 10.8486 & -61.7653 & 53.4 & 6.1 \\
\hline 2006 & 9 & 30 & $17: 50: 22$ & 46.189 & 153.1761 & 19.4 & 6.6 \\
\hline 2006 & 10 & 1 & 9:06:00 & 46.3193 & 153.3046 & 19.5 & 6.5 \\
\hline 2006 & 10 & 9 & $10: 01: 47$ & 20.7054 & 120.0645 & 17.3 & 6.3 \\
\hline 2006 & 10 & 10 & 23:58:06 & 37.1616 & 142.8023 & 32.2 & 6.0 \\
\hline 2006 & 10 & 21 & $18: 23: 20$ & 13.3641 & 121.4278 & 18 & 5.9 \\
\hline 2006 & 10 & 23 & $21: 17: 22$ & 29.411 & 140.3506 & 29.9 & 6.4 \\
\hline 2006 & 11 & 17 & 18:03:11 & 28.5876 & 129.8655 & 23.1 & 6.2 \\
\hline 2006 & 11 & 29 & $15: 38: 43$ & 53.8157 & -35.435 & 10 & 5.6 \\
\hline 2006 & 12 & 1 & $3: 58: 20$ & 3.4573 & 99.103 & 204.2 & 6.3 \\
\hline 2006 & 12 & 25 & 20:00:59 & 42.0738 & 76.0856 & 15.2 & 5.8 \\
\hline 2006 & 12 & 26 & $12: 26: 20$ & 21.8354 & 120.533 & 6.3 & 7.1 \\
\hline 2006 & 12 & 30 & 8:30:47 & 13.205 & 51.3376 & 10 & 6.6 \\
\hline 2007 & 1 & 9 & $15: 49: 32$ & 59.4467 & -137.138 & 10 & 5.7 \\
\hline 2007 & 1 & 17 & $23: 18: 48$ & 10.0815 & 58.7013 & 10 & 6.2 \\
\hline 2007 & 2 & 4 & $20: 56: 57$ & 19.3369 & -78.3947 & 10 & 6.2 \\
\hline 2007 & 2 & 19 & $2: 33: 42$ & 1.6404 & 30.6974 & 27.3 & 5.6 \\
\hline 2007 & 3 & 1 & $23: 11: 50$ & 26.6058 & -44.647 & 10 & 6.0 \\
\hline 2007 & 3 & 6 & $3: 49: 38$ & -0.506 & 100.4824 & 21.2 & 6.4 \\
\hline 2007 & 3 & 9 & $7: 27: 29$ & -11.4284 & 66.2758 & 10 & 5.7 \\
\hline 2007 & 3 & 9 & $3: 22: 42$ & 43.2206 & 133.5123 & 439.5 & 6.0 \\
\hline 2007 & 3 & 13 & 2:59:00 & 26.1733 & -110.697 & 10 & 6.0 \\
\hline 2007 & 3 & 18 & 2:11:03 & 4.6505 & -78.5033 & 1.1 & 6.2 \\
\hline 2007 & 3 & 22 & $6: 10: 43$ & -3.342 & 86.7202 & 26.9 & 5.9 \\
\hline 2007 & 3 & 25 & $0: 41: 56$ & 37.3209 & 136.5686 & 4 & 6.7 \\
\hline 2007 & 3 & 28 & $21: 17: 10$ & -6.2242 & 29.619 & 13.4 & 5.8 \\
\hline 2007 & 4 & 3 & 3:35:06 & 36.4738 & 70.6405 & 215.5 & 6.2 \\
\hline 2007 & 4 & 4 & $19: 58: 02$ & -17.1836 & 66.875 & 10 & 5.9 \\
\hline 2007 & 4 & 5 & $3: 56: 49$ & 37.3659 & -24.6358 & 16.2 & 6.3 \\
\hline 2007 & 4 & 10 & $13: 56: 50$ & 13.0113 & 92.5102 & 15.3 & 5.5 \\
\hline 2007 & 4 & 13 & $5: 42: 21$ & 17.2469 & -100.241 & 33.4 & 6.0 \\
\hline 2007 & 4 & 20 & 1:45:55 & 25.6879 & 125.0772 & 9.2 & 6.3 \\
\hline 2007 & 5 & 4 & $12: 06: 51$ & -1.3273 & -15.0009 & 10 & 6.2 \\
\hline 2007 & 5 & 5 & $8: 51: 38$ & 34.3079 & 81.9875 & 13.4 & 6.1 \\
\hline 2007 & 5 & 7 & $11: 59: 46$ & 31.3215 & 97.6605 & 12 & 5.5 \\
\hline 2007 & 5 & 16 & $8: 56: 13$ & 20.5565 & 100.7342 & 10 & 6.3 \\
\hline 2007 & 5 & 23 & $19: 09: 13$ & 21.9055 & -96.3184 & 1.7 & 5.6 \\
\hline 2007 & 5 & 30 & $20: 22: 11$ & 52.0987 & 157.2889 & 120.4 & 6.4 \\
\hline
\end{tabular}


Table A1. Continued.

\begin{tabular}{|c|c|c|c|c|c|c|c|}
\hline Year & Month & Day & Time UTC & Lat & Long & Depth & $M$ \\
\hline 2007 & 6 & 2 & $21: 34: 58$ & 23.0785 & 101.0073 & 11 & 6.1 \\
\hline 2007 & 6 & 13 & $19: 29: 44$ & 13.7024 & -90.6465 & 64 & 6.7 \\
\hline 2007 & 6 & 15 & $18: 49: 51$ & 1.7332 & 30.7452 & 20.1 & 5.9 \\
\hline 2007 & 6 & 18 & $14: 29: 48$ & 34.4568 & 50.8578 & 11.4 & 5.5 \\
\hline 2007 & 7 & 3 & $8: 25: 59$ & 0.7697 & -30.1971 & 10 & 6.3 \\
\hline 2007 & 7 & 6 & 1:09:18 & 16.5781 & -93.6161 & 120 & 6.1 \\
\hline 2007 & 7 & 13 & $21: 54: 43$ & 51.8785 & -176.246 & 44.1 & 6.0 \\
\hline 2007 & 7 & 15 & $13: 08: 00$ & 52.4899 & -168.032 & 12.5 & 6.1 \\
\hline 2007 & 7 & 16 & $14: 17: 36$ & 36.866 & 134.7943 & 347.1 & 6.8 \\
\hline 2007 & 7 & 17 & $14: 10: 41$ & -2.826 & 36.267 & 14.8 & 5.9 \\
\hline 2007 & 7 & 20 & 10:06:52 & 42.9111 & 82.2962 & 19.1 & 5.6 \\
\hline 2007 & 7 & 29 & $4: 54: 35$ & 53.6067 & 169.7092 & 28 & 5.9 \\
\hline 2007 & 7 & 30 & $22: 42: 05$ & 19.3104 & 95.541 & 15.9 & 5.6 \\
\hline 2007 & 7 & 31 & $22: 55: 28$ & -0.1482 & -17.7189 & 2.7 & 6.2 \\
\hline 2007 & 8 & 2 & $13: 37: 27$ & 12.447 & 47.4593 & 10 & 5.7 \\
\hline 2007 & 8 & 2 & $2: 37: 42$ & 46.9248 & 141.8324 & 19.9 & 6.2 \\
\hline 2007 & 8 & 2 & $5: 22: 16$ & 46.7681 & 141.7716 & 6.9 & 5.8 \\
\hline 2007 & 8 & 2 & $3: 21: 44$ & 51.3075 & -179.975 & 37.8 & 6.7 \\
\hline 2007 & 8 & 7 & $0: 02: 21$ & 27.3494 & 126.7991 & 4.4 & 6.0 \\
\hline 2007 & 8 & 13 & $22: 23: 03$ & -30.9737 & -13.4479 & 10 & 5.5 \\
\hline 2007 & 8 & 15 & $20: 22: 11$ & 50.2629 & -177.554 & 17.8 & 6.5 \\
\hline 2007 & 8 & 16 & $14: 18: 25$ & -3.4566 & -12.1013 & 20.9 & 5.5 \\
\hline 2007 & 8 & 20 & $22: 42: 28$ & 8.1332 & -39.2186 & 10 & 6.5 \\
\hline 2007 & 9 & 1 & $19: 14: 22$ & 25.0103 & -109.64 & 11.9 & 6.1 \\
\hline 2007 & 9 & 3 & $16: 14: 52$ & 45.7243 & 150.1509 & 98.6 & 6.2 \\
\hline 2007 & 9 & 6 & $17: 51: 26$ & 24.3526 & 122.237 & 56.2 & 6.2 \\
\hline 2007 & 9 & 10 & 1:49:12 & 3.0475 & -77.9501 & 27.6 & 6.8 \\
\hline 2007 & 9 & 13 & $3: 35: 27$ & -2.156 & 99.5994 & 18.8 & 7.0 \\
\hline 2007 & 9 & 13 & $2: 30: 01$ & -1.6595 & 99.61 & 24 & 6.5 \\
\hline 2007 & 9 & 20 & $8: 31: 13$ & -2.0015 & 100.064 & 29.1 & 6.7 \\
\hline 2007 & 9 & 26 & $18: 39: 33$ & -7.0062 & -11.6291 & 10 & 5.6 \\
\hline 2007 & 10 & 2 & 18:00:07 & 54.5033 & -161.735 & 42.9 & 6.3 \\
\hline 2007 & 10 & 4 & $12: 40: 29$ & 2.5719 & 92.9055 & 34.7 & 6.2 \\
\hline 2007 & 10 & 18 & $16: 13: 13$ & 30.1823 & -42.6211 & 12.3 & 5.7 \\
\hline 2007 & 10 & 24 & $21: 02: 50$ & -3.9271 & 101.0147 & 28.2 & 6.8 \\
\hline 2007 & 10 & 31 & $3: 04: 54$ & 37.372 & -121.798 & 10 & 5.6 \\
\hline 2007 & 11 & 7 & $7: 10: 20$ & 22.1583 & 92.3702 & 29.7 & 5.5 \\
\hline 2007 & 11 & 27 & $4: 26: 59$ & 16.2324 & 119.824 & 45.3 & 5.9 \\
\hline 2007 & 12 & 6 & $17: 12: 03$ & 22.7483 & -45.1418 & 15.9 & 5.8 \\
\hline 2007 & 12 & 8 & $19: 55: 18$ & -7.5221 & 37.6041 & 10 & 5.6 \\
\hline 2007 & 12 & 12 & $23: 39: 58$ & 52.1242 & -131.437 & 10 & 5.8 \\
\hline 2007 & 12 & 19 & $9: 30: 26$ & 51.3295 & -179.509 & 34.2 & 7.2 \\
\hline 2007 & 12 & 25 & $14: 04: 33$ & 38.4955 & 142.0641 & 48.1 & 6.1 \\
\hline 2007 & 12 & 26 & $22: 04: 55$ & 52.5351 & -168.221 & 34.1 & 6.4 \\
\hline
\end{tabular}


Acknowledgements. Our study is a part of the PASSEQ 2006-2008 project (Wilde-Piórko et al., 2008). The study was partly funded by the NordQuake project. The one-event files were created in the Institute of Geophysics, University of Warsaw, Poland. The figures were produced using Generic Mapping Tools (GMT) (Wessel and Smith, 1991). Data review, picking $P$ wave arrivals and calculations of the theoretical $P$ wave arrivals were performed using the SHM program package (http://www.seismic-handler.org/). Special thanks to Gediminas Motuza and Hanna Silvennoinen for useful discussions. Majdanski work was supported within statutory activity no. 3841/E-41/S/2014 of the Ministry of Science and Higher Education of Poland. We thank Ulrich Achauer, Andreas Fichtner, Jaroslava Plomerova and one anonymous reviewer for useful comments, which helped to improve the manuscript.

7 PASSEQ Working Group: Monika WildePiorko ${ }^{(\mathrm{I})}$, Wolfram H. Geissler (II), Jaroslava Plomerova ${ }^{(\mathrm{III})}$, Marek Grad ${ }^{(\mathrm{I})}$, Vladislav Babuška $^{(I I I)}$, Ewald Bruckl(IV), Jolanta Cyziene ${ }^{(\mathrm{V})}$, Wojciech Czuba $^{(\mathrm{VI})}$, Richard England ${ }^{(\mathrm{VII})}$, Edward Gaczyński ${ }^{(\mathrm{VI})}$, Renata Gazdova $^{(\text {X'III), Soren Gregersen (VIII), Aleksander Guterch }}{ }^{(\mathrm{VI})}$, Winfried Hanka $^{(\text {VII })}$, Endre Hegedûs $\left({ }^{(X)}\right.$, Barbara Heuer ${ }^{(I X)}$, Petr Jedlička $^{(\mathrm{III})}$, Jurga Lazauskiene ${ }^{(\mathrm{V}, \mathrm{XVII})}$, G. Randy Keller ${ }^{(\mathrm{XI})}$, Rainer Kind ${ }^{(\mathrm{IX})}$, Klaus Klinge ${ }^{(\mathrm{XII})}$, Petr Kolinsky(XIII), Kari Komminaho $^{(X I V)}$, Elena Kozlovskaya ${ }^{(X V)}$, Frank Kruger ${ }^{(X V I)}$, Tine Larsen(VIII), Mariusz Majdański(VI), Jiři Malek ${ }^{(\mathrm{XIII})}{ }^{(\mathrm{X}}$, Gediminas $\operatorname{Motuza}^{(\mathrm{XVII})}$, Oldřich Novotny ${ }^{(\mathrm{XIII})}$, Robert Pietrasiak ${ }^{(\mathrm{VI})}$, Thomas Plenefisch $^{(X I I)}$, Bohuslav Růžek ${ }^{(\text {III) }}$, Saulius Sliaupa ${ }^{(V)}$, Piotr Środa ${ }^{(\mathrm{VI})}$, Marzena Świeczak ${ }^{(\mathrm{VI})}$, Timo Tiira ${ }^{(\mathrm{XIV})}$, Peter Voss $^{(\mathrm{VIII})}$, PawełWiejacz ${ }^{(\mathrm{VI})}$. (I) University of Warsaw, Warsaw, Poland; (II) Alfred Wegener Institute for Polar and Marine Research, Bremerhaven, Germany; (III) Institute of Geophysics Czech Academy of Sciences, Prague, Czech Republic; (IV) Vienna University of Technology, Vienna, Austria; (V) Geological Survey of Lithuania, Vilnius, Lithuania; (VI) Institute of Geophysics Polish Academy of Sciences, Warsaw, Poland; (VII) University of Leicester, Leicester, Great Britain; (VIII) Geological Survey of Denmark and Greenland, Copenhagen, Denmark; (IX) GeoForschungsZentrum Potsdam, Potsdam, Germany; (X) Eötvös Loránd Geophysical Institute, Budapest, Hungary; (XI) University of Oklahoma, Norman, USA; (XII) Seismological Central Observatory, Erlangen, Germany; (XIII) Institute of Rock Structure and Mechanics Czech Academy of Sciences, Prague, Czech Republic; (XIV) University of Helsinki, Helsinki, Finland; (XV) University of Oulu, Oulu, Finland; (XVI) University of Potsdam, Potsdam, Germany; (XVII) University of Vilnius, Vilnius, Lithuania.

Special Issue: The Lithosphere-Asthenosphere Boundary (LAB) Dilemma

Edited by: U. Achauer, J. Plomerova, and R. Kind

\section{References}

Aki, K., A. Christoffersson, and Husebye, E. S.: Determination of the three-dimensional seismic structure of the lithosphere, J. Geophys. Res., 82, 277-296, 1977.

Arlitt, R.: Teleseismic body wave tomography across the TransEuropean Suture Zone between Sweden and Denmark, PhD theses, ETH, Swiss Federal Institute of Technology Zürich, Swiss, 1999.
Artemieva, I. M.: Global $1^{\circ} \times 1^{\circ}$ thermal model TC1 for the continental lithosphere: implications for lithosphere secular evolution, Tectonophysics, 416, 245-277, 2006.

Artemieva, I. M.: Dynamic topography of the East European craton: Shedding light upon lithospheric structure, composition and mantle dynamics, Global and Planetary Change, 58, 411-434, 2007.

Artemieva, I. M., Thybo, H., and Kaban, M. K.: Deep Europe today: Geophysical synthesis of the upper mantle structure and lithospheric processes over 3.5 Ga, in: European Lithosphere Dynamics, edited by: Gee, D. and Stephenson, R., Geological Society London, Special Publication, 32, 11-41, 2006.

Babuška V. and Plomerova J.: Subcrustal Lithosphere Around the Saxothuringian-Moldanubian Suture Zone - a model derived from anisotropy of seismic wave velocities, Tectonophysics, 332, 185-199, 2001.

Babuška, V., Plomerova, J., and Fischer, T.: Intraplate Seismicity in the Western Bohemian Massif (Central Europe): A possible correlation with a paleoplate junction, J. Geophysics, 44, 149159, 2007.

Banka, D., Pharao, T. C., Williamson, J. P., and the TESZ Project Potential Field Core Group: Potential field imaging of Paleozoic orogenic structure in northern and central Europe, Tectonophysics, 360, 23-45, 2002.

Belka, Z., Ahrendt, H., Franke, and W., and Wemmer, K.: The Baltica-Gondwana suture in central Europe: evidence from $\mathrm{K}-$ Ar ages of detrital muscovites and biogeographical data, in: Orogenic Processes: Quantification and Modelling of the Variscan Belt, edited by: Franke, W., Haak, V., Oncken, O., and Taner, D., Geological Society, London, 87-102, 2000.

Beller, S., Kozlovskaya, E., Achauer, U., and Tiberi, Ch.: Joint inversion of teleseismic and gravity data beneath the Fennoscandian Shield, EGU General Assembly 2013, Geophys. Res. Abstracts, 15, EGU 2013-4771-2, 2013.

Blundel, D., Freeman, R., and Mueller, S. (Eds.): A Continent Revealed - The European Geotraverse. European Science Foundation, Cambridge University Press, Cambridge, 287 pp., 1992.

Bogdanova, S. V., Gorbatschev, R., Stephenson, R. A., and Guterch A. (Eds.): EUROBRIDGE: Palaeoproterozoic accretion of Fennoscandia and Sarmatia, Tectonophysics, 339, 1-2, 2001.

Bogdanova, S., Gorbatschev, R., Grad, M., Janik, T., Guterch, A., Kozlovskaya, E., Motuza, G., Skridlaite, G., Starostenko, V., Taran, L., and the EUROBRIDGE and POLONAISE Working Groups: EUROBRIDGE: new insight into the geodynamic evolution of the East European Craton, in: European Lithospheric Dynamics. Memoirs Number 32, edited by: Gee, D. G. and Stephenson, R. A., Geological Society, London, 599-625, 2006.

Bogdanova, S. V., Bingen, B., Gorbatschev, R., Kheraskova, T. N, Kozlov, V. I., Puchkov, V. N., and Volozh, Yu. A.: The East European Craton (Baltica) before and during the assembly of Rodinia, Precam. Res., 160, 23-45, 2008.

Bruneton, M., Pedersen, H. A., Farra, V., Arndt, N. T., Vacher, P., Achauer, U., Alinaghi, A., Ansorge, J., Bock, G., Friederich,W., Grad, M., Guterch, A., Heikkinen, P., Hjelt, S.-E., Hyvönen, T. L., Ikonen, J.-P., Kissling, E., Komminaho, K., Korja, A., Kozlovskaya, E., Nevsky, M. V., Paulssen, H., Pavlenkova, N. I., Plomerová, J., Raita, T., Riznichenko, O. Y., Roberts, R. G., Sandoval, S., Sanina, I. A., Sharov, N. V., Shomali, Z. H., Tiikkainen, J., Wielandt, E., Wilegalla, K., Yliniemi, J., and Yurov, Y. G.: 
Complex lithospheric structure under the central Baltic Shield from surface wave tomography, J. Geophys. Res., 109, B10303, doi:10.1029/2003JB002947, 2004.

Cotte, N., Pedersen, H. A., and TOR Working Group: Sharp contrast in lithospheric structure across the Sorgenfrei-Tornquist zone as inferred by Rayleigh wave analysis of TOR 1 project data, Tectonophysics, 360, 75-88, 2002.

Czuba, W., Grad, M., Luosto, U., Motuza, G., Nasedkin, V., and POLONAISE P5 Working Group: Crustal structure of the East European craton along the POLONAISE'97 P5 profile, Acta Geoph. Pol., 49, 145-168, 2001.

Dadlez, R., Grad, M., and Guterch, A.: Crustal structure below the Polish Basin: Is it composed of proximal terranes derived from Baltica?, Tectonophysics, 411, 111-128, 2005.

Dörr W., Belka Z., Marheine D., Schastok J., Valverde Vaquero P., and Wiszniewska J.: U-Pb and $\mathrm{Ar}-\mathrm{Ar}$ geochronology of anorogenic granite magmatism of the Mazury complex NE Poland, in: Precambrian Research, edited by: Rämo, T., Special issue, 119, 101-102, 2002.

Eaton, D. W., Darbyshire, F., Evans, R. L., Grütter, H., Jones, A. G., and Yuan, X.: The elusive lithosphere-asthenosphere boundary (LAB) beneath cratons, Lithos, 109, 1-22, 2009.

EUROBRIDGE SeismicWorking Group: Seismic velocity structure across the Fennoscandia-Sarmatia suture of the East European Craton beneath the EUROBRIDGE profile through Lithuania and Belarus, Tectonophysics, 314, 193-217, 1999.

EUROBRIDGE Working Group, and EUROBRIDGE'95: Deep seismic profiling within the East European Craton, Tectonophysics, 339, 153-175, 2001.

Franke, W. and Zelazniewicz, A.: The Eastern Termination of the Variscides: Terrane Correlation and Kinematic Evolution in Orogenic processes: quantification and modelling in the Variscan Belt, Special Publications, edited by: Franke W., Haak W., Oncken O., and Tanner, D., Geol. Soc., London, 179, 63-85, 2000.

Garetskii, R. G., Boborykin, A. M., Bogino, V. A., German, V. A., Veres, S. A., Klushin, S. V., and Shafaruk, V. G.: Deep seismic sounding on the territory of Belorussia, Geophys. J. Internat., 8, 439-448, 1990.

Gee, D. G. and Stephenson, R. A.: The European lithosphere: an introduction, in: European Lithophere Dynamics, edited by: Gee, D. G. and Stephenson, R. A., Geol. Soc. Lond. Mem., 32, 1-9, 2006.

Geissler, W. H., Sodoudi, F., and Kind, R.: Thickness of the central and eastern European lithosphere as seen by $S$ receiver functions, Geophys. J. Int., 181, 604-634, 2010.

Grad, M. and Tripolsky, A.: Crustal structure from P and S seismic waves and petrological model of the Ukrainian shield, Tectonophysics, 250, 89-112, 1995.

Grad, M., Keller, G. R., Thybo, H., Guterch, A., and POLONAISE Working Group: Lower lithospheric structure beneath the TransEuropean Suture Zone from POLONAISE'97 seismic profiles, Tectonophysics, 360, 153-168, 2002.

Grad, M., Janik, T., Guterch, A., Sroda, P., Czuba, W., and EUROBRIDGE'94-97, POLONAISE'97 and CELEBRATION 2000 Seismic Working Groups: Lithospheric structure of the western part of the East European Craton investigated by deep seismic profiles, Geol. Quart., 50, 9-22, 2006.

Gregersen, S., Pedersen, L. B., Roberts, R. G., Shomali, H., Berthelsen, A., Thybo, H., Mosegaard, K., Pedersen, T., Voss, P.,
Kind, R., Bock, G., Gossler, J., Wylegala, K., Rabbel, W., Woelbern, I., Budweg, M., Busche, H., Korn, M., Hock, S., Guterch, A., Grad, M., Wilde-Piorko, M., Zuchniak, M., Plomerova, J., Ansorge, J., Kissling, E., Arlitt, R., Waldhauser, F., Ziegler, P., Achauer, U., Pedersen, H., Cotte, N., Paulssen, H., and Engdahl, E. R.: Important findings expected from Europe's largest seismic array. Eos, Trans. Am. Geophys. Union, 80, 1-6, 1999.

Gregersen, S., Voss, P., Nielsen, L. V., Achauer, U., Busche, H., Rabbel, W., and Shomali, Z. H.: Uniqueness of modeling results from teleseismic $\mathrm{P}$ wave tomography in Project TOR, Tectonophysics, 481, 99-107, 2010.

Griffin, W. L., O’Reilly, S. Y., Abe, N., Aulbach, S., Davies, R. M., Pearson N. J., Doyle, B. J., and Kivi, K.: The origin and evolution of Archean lithospheric mantle, Precam. Res., 127, 19-41, 2003.

Guterch, A. and Grad, M.: Seismic structure of the Earth's crust between Precambrian and Variscan Europe in Poland, Publs. Inst. Geophys. Pot. Acad. Sc., M-18, 67-73, 1996.

Guterch, A. and Grad, M.: Lithospheric structure of the TESZ in Poland based on modern seismic experiments, Geol. Quart., 50, 23-32, 2006.

Guterch, A., Grad, M., Thybo, H., Keller, G. R., and the POLONAISE Working Group: POLONAISE'97 - an international seismic experiment between Precambrian and Variscan Europe in Poland, Tectonophysics 314, 101-121, 1999.

Guterch, A., Grad, M., Keller, G. R., and POLONAISE'97, CELEBRATION 2000, ALP 2002, SUDETES 2003 Working Groups: Huge contrasts of the lithospheric structure revealed by new generation seismic experiments in Central Europe, Przegld Geologiczny, 52, 2004.

Hansen, T. M. and Balling, N.: Upper-mantle reflectors: modeling of seismic wavefield characteristics and tectonic implications, Geophys. J. Int, 157, 664-682, 2004.

Johnston, A. C., Coppersmith, K. J., Kanter, L. R., and Cornell, C. A.: The earthquakes of stable continental regions. Elektric Power Institute, Report in Vol. 1: Assessment of Large Earthquake Potential, no. TR-102261-V1, 1994.

Jones, A. G., Plomerova, J., Korja, T., Sodoudi, F., and Spakman, W.: Europe from the bottom up: A statistical examination of the central and northern European lithosphere-asthenosphere boundary from comparing seismological and electromagnetic observations, Lithos, 120, 14-29, 2010.

Karousova, H., Plomerova, J., and Babuska, V.: Upper-mantle structure beneath the southern Bohemian Massif and its surroundings imaged by high-resolution tomography, Geophys. J. Int., 194, 1203-1215, doi:10.1093/gji/ggt159, 2013.

Knapmeyer-Endrun, B., Krüger, F., Legendre, C. P., Geissler, W. H., and PASSEQ Working Group: Tracing the influence of the TransEuropean Suture Zone into the mantle transition zone, Earth Planet. Sci. Lett., 363, 73-87, 2013a.

Knapmeyer-Endrun, B., Krüger, and PASSEQ Working Group: Imaging the lithosphere-asthenosphere boundary across the transition from Phanerozoic Europe to the East-European Craton with S-receiver functions, Geophys. Res. Abstr., 15, EGU20136972, 2013b.

Korja, T.: How is the European Lithosphere Imaged by Magnetotellurics?, Surv. Geophys., 28, 239-272, .2007.

Kostyuchenko, S. L., Egorkin, A. V., and Solodilov, L. N.: Structure and genetic mechanisms of the Precambrian rifts of the East Eu- 
ropean Platform in Russia by integrated study of seismic, gravity, and magnetic data, Tectonophysics, 313, 9-28, 1999.

Koulakov, I., Kaban, M. K., Tesauro M., and Cloetingh S.: P- and $\mathrm{S}$-velocity anomalies in the upper mantle beneath Europe from tomographic inversion of ISC data, Geophys. J. Int., 179, 345366, 2009.

Legendre, C. P., Meier, T., Lebedev, S., Friederich, W., and ViereckGötte, L.: A shear wave velocity model of the European upper mantle from automated inversion of seismic shear and surface waveforms, Geophys. J. Int., 191, 282-304, 2012.

Majdański, M.: The structure of the crust in TESZ area by kriging interpolation, Acta Geophys., 60, 59-75, 2012.

Majorowicz, J. A., Čermak, V., Šafanda, J., Krzywiec, P., Wróblewska, M., Guterch, A., and Grad, M.: Heat flow models across the Trans-European Suture Zone in the area of the POLONAISE'97 seismic experiment, Phys. Chem. Earth, 28, 375-391, 2003.

Malinowski, M., Grad, M., Guterch, A., and CELEBRATION 2000 Working Group: Three-dimensional seismic modelling of the crustal structure between East European Craton and the Carpathians in SE Poland based on CELEBRATION 2000 data, Geophys. J. Int., 173, 546-565, 2008.

Matzel, E. and Grand, S. P.: The anisotropic structure of the East European platform, J. Geophys. Res., 109, B01302, doi:10.1029/2001JB000623, 2004.

McKenzie, D. P.: Some remarks on the heat flow and gravity anomalies, J. Geophys. Res., 72, 6261-6273, 1967.

Menke, W.: Geophysical data analysis: Discrete inverse theory, Academic Press, Inc., Orlando, Fl., 260 pp., 1984.

Motuza, G.: Žemès plutos bei kristalinio pamato sandaros ir sudéties raida, in: Lietuvos žemès gelmiụ raida ir ištekliai, edited by: Baltrūnas, V., UAB Petro ofsetas, Vilnius, 11-40, 2004.

Motuza, G.: Structure and formation of the crystalline crust in Lithuania, Mineralogical Society of Poland, Special Papers, 26, 67-79, 2005.

Motuza, G. and Staškus, V.: Seniausios Lietuvos uolienos, Geologijos akiračiai, ISSN 1392-0006, 3/4, 41-47, 2009.

Nolet, G. and Zielhuis, A.: Low $\mathrm{S}$ velocities under the TornquistTeisseyre zone: evidence from water injection into the transition zone by subduction, J. Geophys. Res., 99, 15813-15820, 1994.

Pharaoh, T. C.: Paleozoic terranes and their lithospheric boundaries within the Trans-European Suture Zone (TESZ): a review, Tectonophysics, 314, 17-41, 1999.

Pharaoh, T. C. and TESZ Project Core Group: EUROPROBE TransEuropean Suture Zone project. British Geological Survey, EUROPROBE News 12, June 2000, 2000.

Pharaoh, T. C., England, R. W., Verniers, J., and Zelainiewicz, A.: Introduction: geological and geophysical studies in the TramEuropean Suture Zone, Geol. Mug., 134, 585-590, 1997.

Plomerova, J. and Babuska, V.: Seismic anisotropy of the lithosphere around the Trans-European suture zone (TESZ) based on teleseismic body-wave data of the TOR experiment, Tectonophysics, 360, 89-114, 2002.

Plomerova, J. and Babuska, V.: Long memory of mantle lithosphere fabric - European LAB constrained from seismic anisotropy, Lithos, 120, 131-143, 2010.

Plomerova J., Babuška V., Sileny J., and Horalek, J.: Seismic anisotropy and velocity variations in the mantle beneath the Saxothuringicum-Moldanubicum con- tact in central Europe, in: Geodynamics of Lithosphère and Earh's Mantle: Seismic Anisotropy as a Recird of the Past and Present Dynamic Processes, edited by: Plomerova, J., Liebermann, R. C., and Babuška, V., Pure and Appi. Geoph., Special issue, 151 pp., 1998.

Plomerova, J., Kouba, D., and Babuska, V.: Mapping the lithosphere-asthenosphere boundary (LAB) through changes in surface-wave anisotropy, Tectonophysics, 358, 175-185, 2002.

Plomerova, J., Achauer, U., Babuska, V., Vecsey, L., and BOHEMA Working Group: Upper mantle beneath the Eger Rift (Central Europe): plume or asthenosphere upwelling?, Geophys. J. Int., 169, 675-682, 2007.

Plomerova, J., Babuska, V., Kozlovskaya, E., Vecsey, L., and Hyvonen, L. T.: Seismic anisotropy - a key to resolve fabrics of mantle lithosphere of Fennoscandia, Tectonophysics, 462, 125-136, 2008.

Praus, O., Pěčová, J., Petr, V., Babuska, V., and Plomerova, J.: Magnetotelluric and seismological determination of the lithosphereasthenosphere transition in Central Europe, Phys. Earth Planet Int., 60, 212-228, 1990.

Rämö, O. T., Huhma, H., and Kirs, J.: Radiogenic Isotopes of the Estonian and Latvian Rapakivi Granite Suite: New Data from the Concealed Precambrian of the East European Craton, Precam. Res., 79, 209-226, 1996.

Sandoval, S., Kissling, E., Ansorge, J., and the SVEKALAPKO STWG: High- Resolution body wave tomography beneath the SVEKALAPKO array: I. A-priori 3-D crustal model and associated traveltime effects on teleseismic wavefronts, Geoph. J. Int., 153, 75-87, 2003.

Sandoval Castano, S.: The Lithosphere-Asthenosphere System beneath Fennoscandia (Baltic Shield) by Body-wave Tomography, A dissertation submitted to the Swiss Federal Institute of Technology Zurich, 2002.

Shomali, Z. H., Roberts, R. G., Pedersen, L. B., and the TOR Working Group: Lithospheric structure of the Tornquist Zone resolved by nonlinear $\mathrm{P}$ and $\mathrm{S}$ teleseismic tomography along the TOR array, Tectonophysics, 416, 133-149, 2006.

Skridlaite, G. and Motuza, G.: Precambrian domains in Lithuania: evidence of terrane tectonics, Tectonophysics, 339, 113-133, 2001.

Sroda, P. and the POLCRUST and PASSEQ Working Groups: Seismic anisotropy and deformations of the TESZ lithosphere near the East European Craton margin in SE Poland at various scales and depths, EGU General Assembly 2014, Geophys. Res. Abstracts, Vol. 16, EGU2014-6463-1, 2014.

Steck, L. K. and Prothero, W. A. J.: A 3-D raytracer for teleseismic body-wave arrival times, Bull. Seism. Soc. Am., 81, 1332-1339, 1991.

Tesauro, M., Kaban, M. K., and Cloetingh, S. A. P. L.: EuCRUST07: A new reference model for the European crust, Geophys. Res. Lett., 35, L05313, doi:10.1029/2007GL32244, 2008.

Thybo, H.: Crustal structure and tectonic evolution of the Tornquist Fan region as revealed by geophysical methods, Bull. Geol. Soc. Den., 46, 145-160, 2000.

Thybo, H., Janik, T., Omelchenko, V. D., Grad, M., Garetsky, R. G., Belinsky, A. A., Karatayev, G. I., Zlotski, G., Knudsen, M. E., Sand, R., Yliniemi, J., Tiira, T., Luosto, U., Komminaho, K., Giese, R., Guterch, A., Lund, C.-E., Kharitonov, O. M., Ilchenko, T., Lysynchuk, D. V., Skobelev, V. M., and Doody, J. J.: Upper 
lithospheric seismic velocity structure across the Pripyat Trough and the Ukrainian Shield along the EUROBRIDGE'97 profile, Tectonophysics, 371, 41-79, 2003.

Vecsey, L., Plomerova, J., Babuska, V., and PASSEQ Working Group: Structure of the mantle lithosphere around the TESZ - from the East European Craton to the Variscan Belt. EGU General Assembly 2013, Geophys. Res. Abstracts, Vol. 15, EGU2013-3133, 2013.

Vinnik, L. P. and Ryaboy, V. Z.: Deep structure of the East European platform according to seismic data, Phys. Earth Planet. Inter., 25, 27-37, 1981.

Wagner, G. A., Gögen, K., Jonckheere, R., Wagner, I., and Woda, C.: Dating the Quarternary volcanoes Komorní Hurka (Kammerbühl) and Železná Hurka (Eisenbühl), Czech Republic, by TL, ESR, alpha-recoil and fission track chronometry, Z. Geol. Wiss., 30, 191-200, 2002.

Weiland, C. M., Steck, L. K., Dawson, P. B., and Korneev, V. A.: Nonlinear teleseismic tomography at Long Valley caldera, using three-dimensional minimum travel time ray tracing, J. Geophys. Res., 100, 20379-20390, 1995.

Wessel, P. and Smith, W.: Free software helps map and display data, EOS, Trans. Am. Union 72, 441 pp., 1991.

Wilde-Piorko, M., Grad, M., and TOR Working Group: Crustal structure variation from the Precambrian to Palaeozoic platforms in Europe imaged by the inversion of teleseismic receiver functions - project TOR, Geophys. J. Internat., 150, 261-270, 2002.

Wilde-Piórko, M., Geissler, W.H., Plomerová, J., Grad, M., Babuška, V., Brückl, E., Čyžienè, J., Czuba, W., Eengland, R., Gaczyński, E., Gazdova, R., Gregersen, S., Guterch, A., Hanka, W., Hegedűs, E., Heuer, B., Jedlička, P., Lazauskienė, J., Randy Keller, G., Kind, R., Klinge, K., Kolinsky, P., Komminaho, K., Kozlovskaya, E., Krűger, F., Larsen, T., Majdański, M., Málek, J., Motuza, G., Novotný, O., Pietrasiak, R., Plenefish, Th., Rǔžek, B., Šliaupa, S., Środa, P., Świeczak, M., Tiira, T., Voss, P., and Wiejacz, P.: PASSEQ 2006-2008: PASsive Seismic Experiment in Trans-European Suture Zone, Stud. Geophys. Geod., 52, 439448, 2008.
Wilde-Piórko, M., Świeczak, M., Grad, M., and Majdański, M.: Integrated seismic model of the crust and upper mantle of the Trans-European Suture zone between the Precambrian craton and Phanerozoic terranes in Central Europe, Tectonophysics, 481, 108-115, 2010.

Winchester, J. A. and the PACE TMR Network Team: Paleozoic amalgamation of Central Europe: new results from recent geological and geophysical investigations, Tectonophysics, 360, 521, 2002.

Wüstefeld, A., Bokelmann, G., and Barruol, G.: Evidence for ancient lithospheric deformation in the East European Craton based on mantle seismic anisotropy and crustal magnetics, Tectonophysics, 481, 16-28, 2010.

Yliniemi, J., Kozlovskaya, E., Hjelt, S. E., Komminaho, K., and Ushakov, A.: Structure of the crust and uppermost mantle beneath southern Finland revealed by analysis of local events registered by the SVEKALAPKO seismic array, Tectonophysics, 394, 41-67, 2004.

Zhu, H., Bozdağ, E., Peter, D., and Tromp, J.: Structure of the European upper mantle revealed by adjoint tomography, Nat. Geosci., 5, 493-498, 2012.

Zielhuis, A. and Nolet, G.: Deep seismic expression of the ancient plate boundary in Europe, Science, New Series, 265, 79-81, 1994. 